\title{
Modeling Gross Primary Production of a Typical Coastal Wetland in China Using MODIS Time Series and $\mathrm{CO}_{2}$ Eddy Flux Tower Data
}

\author{
Xiaoming Kang ${ }^{1,2,3}$, Liang Yan ${ }^{1,2}$, Xiaodong Zhang ${ }^{1,2}$, Yong $\mathrm{Li}^{1,2}$, Dashuan Tian ${ }^{4}$, \\ Changhui Peng ${ }^{3,5}$, Haidong Wu ${ }^{1,2}$, Jinzhi Wang ${ }^{1,2, *}$ and Lei Zhong ${ }^{6, *}$ \\ 1 Beijing Key Laboratory of Wetland Services and Restoration, Institute of Wetland Research, \\ Chinese Academy of Forestry, Beijing 100091, China; xmkang@ucas.ac.cn (X.K.); casyanliang@126.com (L.Y.); \\ babara_1102@163.com (X.Z.); hnohno@163.com (Y.L.); whd2752@126.com (H.W.) \\ 2 Sichuan Zoige Wetland Ecosystem Research Station, Tibetan Autonomous Prefecture of Aba 624500, China \\ 3 Department of Biology Science, Institute of Environment Sciences, University of Quebec at Montreal, \\ Montreal, QC C3H 3P8, Canada; peng.changhui@uqam.ca \\ 4 Key Laboratory of Ecosystem Network Observation and Modeling, Institute of Geographic Sciences and \\ Natural Resources Research, Chinese Academy of Sciences, Beijing 100101, China; tiands@igsnrr.ac.cn \\ 5 Center for Ecological Forecasting and Global Change, College of Forestry, Northwest Agriculture and Forest \\ University, Yangling 712100, China \\ 6 School of Environmental Science and Engineering, Tianjin University, China-Australia Centre for \\ Sustainable Urban Development, Tianjin 300072, China \\ * Correspondence: wangjz04@126.com (J.W.); lei.zhong@tju.edu.cn (L.Z.); Tel.: +86-10-6282-4182 (J.W.)
}

Received: 19 March 2018; Accepted: 3 May 2018; Published: 4 May 2018

\begin{abstract}
How to effectively combine remote sensing data with the eddy covariance (EC) technique to accurately quantify gross primary production (GPP) in coastal wetlands has been a challenge and is also important and necessary for carbon (C) budgets assessment and climate change studies at larger scales. In this study, a satellite-based Vegetation Photosynthesis Model (VPM) combined with EC measurement and Moderate Resolution Imaging Spectroradiometer (MODIS) data was used to evaluate the phenological characteristics and the biophysical performance of MODIS-based vegetation indices (VIs) and the feasibility of the model for simulating GPP of coastal wetland ecosystems. The results showed that greenness-related and water-related VIs can better identify the green-up and the senescence phases of coastal wetland vegetation, corresponds well with the $C$ uptake period and the phenological patterns that were delineated by GPP from EC tower (GPP $\left.\mathrm{EC}_{\mathrm{C}}\right)$. Temperature can explain most of the seasonal variation in VIs and GPP $\mathrm{EC}_{\mathrm{EC}}$ fluxes. Both enhanced vegetation index (EVI) and water-sensitive land surface water index (LSWI) have a higher predictive power for simulating GPP in this coastal wetland. The comparisons between modeled GPP (GPP $\left.{ }_{\mathrm{VPM}}\right)$ and $\mathrm{GPP}_{\mathrm{EC}}$ indicated that VPM model can commendably simulate the trajectories of the seasonal dynamics of $\mathrm{GPP}_{\mathrm{EC}}$ fluxes in terms of patterns and magnitudes, explaining about $85 \%$ of $\mathrm{GPP}_{\mathrm{EC}}$ changes over the study years $(p<0.0001)$. The results also demonstrate the potential of satellite-driven VPM model for modeling $C$ uptake at large spatial and temporal scales in coastal wetlands, which can provide valuable production data for the assessment of global wetland $C$ sink/source.
\end{abstract}

Keywords: coastal wetland; eddy covariance; gross primary production; MODIS; vegetation indices; VPM

\section{Introduction}

As a staggered transition zone of terrestrial ecosystem and marine ecosystem, coastal wetland constitutes chains of marshes and swamps, and provides valuable ecosystem services and benefits 
to human [1-4]. It plays an important role in the principal interchanges of material and energy and the global sequestration of carbon $(C)[1,5,6]$. As the key component of the $C$ cycle, gross primary production (GPP) represents the capacity of vegetation to uptake $C$ from the atmosphere [7-10]. However, global-scale and measurement-based estimation of the historical growth in GPP is still lacking. The dynamics of GPP in coastal wetlands and its response to global climate change is poorly quantified and understood [5,11,12]. Therefore, accurate quantification of GPP for coastal wetlands at various spatial and temporal scales is crucial and necessary for global $\mathrm{C}$ budgets assessment and climate change studies [13].

The eddy covariance (EC) method and remote sensing (RS) technology have greatly increased the opportunities for the quantification of GPP at regional or global scales. The EC method can continuously and reliably measure net exchanges of $C$, water and energy between atmosphere, and terrestrial ecosystems at the diurnal, seasonal, and annual scales [14-17]. It can be used for calibrating and validating ecological models by providing important information that is associated with photosynthetic period and GPP at the ecosystem scale [18-20]. However, C flux data provided by the EC method is limited by footprints (typically ranging from hundreds of meters to $1 \mathrm{~km}$ ) and short time periods [21-24]. Satellite RS technology can alternatively provide rapid, continuous, systematic, and repetitive measurement of vegetation structure and function characterization over large areas [23,25]. It is an effective and powerful tool for monitoring properties of land surface and obtaining spatiotemporal information, and then estimating regional GPP and net primary production (NPP), which can be consistent with the EC tower footprint [26,27]. However, there is still lacking interrelated links and bridges between EC and RS.

The satellite-based model is the interrelated links and bridges between EC measurement and RS data at regional scale. Among many RS models, the production efficiency models (PEM) are widely used in the GPP estimation study because of its lesser number of driving parameters, accurate estimation, and the easier coupling of EC and RS [23,28-31]. These models generally predict GPP by light use efficiency $\left(\varepsilon_{\mathrm{g}}\right)$, photosynthetically active radiation (PAR), the fraction of the absorbed PAR by the vegetation canopy (FAPAR), and a greenness-related Normalized Difference Vegetation Index (NDVI) [32]. Recently, Xiao et al., has developed a RS-based vegetation photosynthesis model (VPM) to simulate GPP [33-35]. VPM is a well-established GPP model by the conceptual partitioning of chlorophyll and non-photosynthetically active vegetation within the canopy to simulate GPP [36]. The model used additional spectral bands, such as blue and shortwave infrared bands to calculate the Enhanced Vegetation Index (EVI) [37] and Land Surface Water Index (LSWI) [33,36,38]. For example, Li et al., used the improved EVI and LSWI as input data for the VPM model to better characterize the dynamics of vegetation. They also simulated GPP more accurately than other PEM models, which only used NDVI in Qinghai-Tibetan Plateau, China [23]. Recently, this model has been further developed and applied to several ecosystems, including forest, grassland, agriculture, and alpine wetland ecosystems $[10,13,15,23,33,36,39,40]$, which demonstrated the potential to scale up in situ observations of GPP from the $\mathrm{CO}_{2}$ flux tower sites.

As the largest wetland ecosystem in the warm temperate zone of China, the Yellow River Delta Wetland is the most active area of atmosphere-land-ocean interaction in the world [41-44]. Therefore, the accurate estimation of the $\mathrm{C}$ source/sink function and its influence mechanism for the targeted coastal wetland will help to quantify the interactions and feedbacks between global climate change and coastal wetland ecosystems. In this study, we have combined the analysis of EC flux data with remote sensing images in the Yellow River Delta during 2009-2010. We aim to: (i) characterize seasonal dynamics of reed by analyzing the Moderate Resolution Imaging Spectroradiometer (MODIS) vegetation indices (VIs) and $\mathrm{CO}_{2}$ fluxes data; (ii) examine the biophysical expression of VIs related to seasonal dynamics of observed GPP data; and, (iii) evaluate the dependability and the applicability of the VPM model for simulating GPP of coastal wetland ecosystems. We also conducted a variety of uncertainty analysis for the model simulations. This study could help to deepen our understanding of 
C budgets of coastal wetland and further improve the potential of RS technology for monitoring and simulating the dynamics of regional vegetation and $C$ fluxes.

\section{Materials and Methods}

\subsection{Description of the Study Region}

Our study was carried out in the Yellow River Delta Nature Reserve $\left(37^{\circ} 45^{\prime} 59^{\prime \prime} \mathrm{N}, 119^{\circ} 09^{\prime} 05^{\prime \prime}\right.$ E, $-4 \mathrm{~m}$ above sea level; Figure 1). The nature reserve covers an area of $15.3 \times 10^{4}$ ha. Our EC tower was established at the coastal zone of the Yellow River Delta Nature Reserve. In this region, the dominant wind direction is the north and northwest wind. The average annual wind speed is about $4 \mathrm{~m} / \mathrm{s}$. The annual mean air temperature is $12.1{ }^{\circ} \mathrm{C}[41,45]$. The annual mean precipitation is $520 \mathrm{~mm}$, which mainly concentrates in summer. The annual evaporation is $1962 \mathrm{~mm}$ and frost-free period is 196 days. The dominated soil type is coastal saline soil. The $\mathrm{pH}$ of the soil is 7.6-8.5. The dominant vegetation includes both the herbaceous plants (Phragmites australis and Suaeda salsa) and the shrub (Tamarix chinensis). The height of plants ranges from 120 to $200 \mathrm{~cm}$.

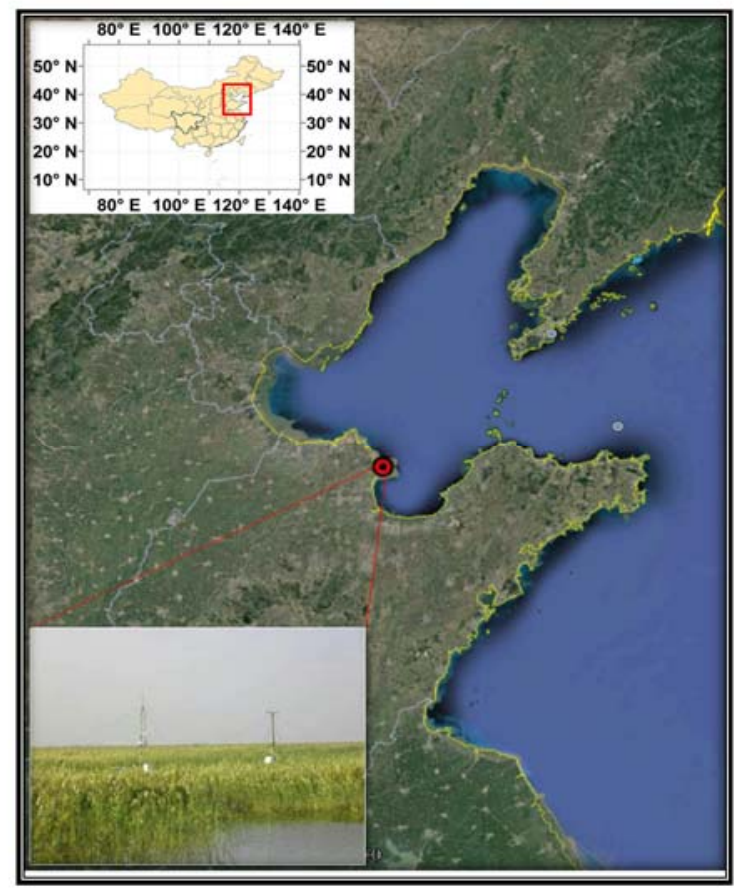

Figure 1. Study site location at the Yellow River Delta. The remote sensing data is derived from Google Earth. The eddy covariance system, including a flux tower and a weather station, was deployed at the coastal zone of Yellow River Delta Nature Reserve in 2008, with observation of $\mathrm{CO}_{2}$ and water fluxes, air temperature, precipitation, photosynthetically active radiation (PAR), etc.

\section{2. $\mathrm{CO}_{2}$ Flux and Climate Data from the Eddy Flux Tower Site}

The EC instrument was established at the study site since 2008 (Figure 1), with the observation of $\mathrm{CO}_{2}$ and water fluxes, wind speed, and wind direction. The EC tower equipped with an open path infrared $\mathrm{CO}_{2} / \mathrm{H}_{2} \mathrm{O}$ gas analyzer (Li 7500, LI-COR Inc., Lincoln, NE, USA) and ultrasonic anemometer (CSAT3, Campbell Scientific Inc., Jackson, MS, USA), which were installed $4.5 \mathrm{~m}$ above ground level. The sonic anemometer and the infrared $\mathrm{CO}_{2} / \mathrm{H}_{2} \mathrm{O}$ gas analyzer output were recorded at half-hour intervals by datalogger (CR5000, Campbell Scientific, Inc., Jackson, MS, USA), with high frequency of $10 \mathrm{~Hz}$. Carbon and energy fluxes were calculated by using the half-hour covariance of vertical wind velocity and virtual temperature, water vapor density, and $\mathrm{CO}_{2}$ density [15]. 
We also measured some environmental factors that were used for gap filling calculations nearby the eddy tower. Photosynthetically active radiation (PAR) was observed by LI-190SB sensors (LI-COR Inc., Lincoln, NE, USA). Relative humidity and air temperature were observed by humidity/temperature probes (HMP45C, VAISALA Woburn, MA, USA). Precipitation was measured at the height of $1.5 \mathrm{~m}$ above the ground level by a tipping bucket rain-gauge (TE525MM, Campbell Scientific, Inc., Jackson, MS, USA). The copper-constantan thermocouples were installed at five depths $(0.05,0.10,0.20,0.50$, and $1.0 \mathrm{~m})$ below the ground to measure soil temperature. All data were saved in the digital datalogger (CR23X; Campbell Scientific, Inc., Jackson, MS, USA) [19].

For reducing the measurement-induced uncertainties, quality control was conducted for the observed data during 2009-2010. The $\mathrm{CO}_{2}$ flux data observed during rainfall or snowfall or instrument failure (e.g., system maintenance, power outages, etc.) were eliminated as invalid data that has led to data gaps. To fill the $\mathrm{CO}_{2}$ flux data gap, the gap filling methods, including mean diurnal variation (MDV), of previous periods and nonlinear regression were used in this study. For the MDV method, the means for different time interval (window size, usually 4-15 days) that were based on adjacent days were used to replace the missing flux data. Nonlinear regression method was interpolated by establishing the regression relationships between net ecosystem $\mathrm{CO}_{2}$ exchanges (NEE) components and the associated environmental factors during the studied period [46].

Generally, the EC measured C fluxes represent NEE, which is the balance between ecosystem respiration $\left(R_{\mathrm{e}}\right)$ and GPP [47]. Therefore, GPP can be obtained by the difference between $R_{\mathrm{e}}$ and NEE. $R_{\mathrm{e}}$ is summed by the daytime $\left(R_{\mathrm{e}, \mathrm{day}}\right)$ and nighttime $\left(R_{\mathrm{e}, \text { night }}\right)$ ecosystem respiration. $R_{\mathrm{e}, \text { night }}$ is derived from the nighttime NEE. Because $R_{\mathrm{e}, \text { night }}$ is relevant to the soil temperature $\left(T_{\mathrm{s}}\right)[15,48]$, a temperature dependent model was derived from the observed $R_{\mathrm{e}, \text { night }}$ with $T_{\mathrm{s}}$ [19]. Then, we estimated the $R_{\mathrm{e}, \mathrm{day}}$ rates and GPP by extrapolating the exponential relationship to the daytime periods.

$$
\begin{gathered}
G P P=R_{e}-N E E \\
R_{e}=R_{\mathrm{e}, \text { day }}+R_{\mathrm{e}, \text { night }} \\
R_{\mathrm{e}, \text { night }}=a e^{(b T s)}
\end{gathered}
$$

where $T_{\mathrm{s}}$ is soil temperature $\left({ }^{\circ} \mathrm{C}\right)$ at the depth of $0.05 \mathrm{~m}$, and $a$ and $b$ are coefficients. During the data processing, the unit of $\mathrm{CO}_{2}$ fluxes (NEE, GPP, $R_{\mathrm{e}}, R_{\mathrm{e}, \text { day, }} R_{\mathrm{e}, \text { night }}$ ) is $\mathrm{mg} \mathrm{CO}_{2} \mathrm{~m}^{-2} \mathrm{~s}^{-1}$. After that, we accumulated and converted all data to the whole day, and obtained the daily $\mathrm{CO}_{2}$ flux data, when the unit of $\mathrm{CO}_{2}$ fluxes (NEE, GPP, $R_{\mathrm{e}}$ ) is $\mathrm{g} \mathrm{CO}_{2} \mathrm{~m}^{-2}$ day $^{-1}$ or $\mathrm{g} \mathrm{C} \mathrm{m}^{-2}$ day ${ }^{-1}$.

The daily GPP and climate data were aggregated to eight-day intervals in order to be consistent with MODIS eight-day composites. The aggregated eight-day GPP and climate data over 2009-2010 were utilized as parameter, input, and validated data in this study to support model simulation and validation.

\subsection{Moderate Resolution Imaging Spectroradiometer Data and Vegetation Indices}

The time series site-specific VIs for the targeted wetland EC tower were extracted from the MODIS datasets. We mainly used seven spectral bands to study vegetation and land surface: blue $(459-479 \mathrm{~nm})$, green $(545-565 \mathrm{~nm})$, red $(620-670 \mathrm{~nm})$, near infrared (NIR, 841-875 nm, 1230-1250 nm), and shortwave infrared (SWIR, 1628-1652 nm, 2105-2155 nm). In this study, based on the location (latitude and longitude) of the targeted EC tower, we downloaded the eight-day MOD09A1 data over 2009-2010 from Earth Observation and Modeling Facility (EOMF), the University of Oklahoma website (http:/ / www.eomf.ou.edu). Then, we calculated EVI [37], LSWI [33], and NDVI [32] based on the reflectance values of the eight-day MODIS dataset from the blue, red, NIR, and SWIR spectral bands [33]. Owing to some defects of the NDVI, the EVI was proposed by using a feedback-based approach that incorporates both background adjustment and atmospheric resistance concepts into the NDVI, resulting in a feedback-based, soil and atmosphere resistant vegetation index [37]. Furthermore, 
VPM model used EVI and LSWI as important input data to simulate the dynamics of GPP at the targeted coastal wetland.

$$
\begin{gathered}
E V I=2.5 \times \frac{\rho_{\text {nir }}-\rho_{\text {red }}}{\rho_{\text {nir }}+\left(6 \times \rho_{\text {red }}-7.5 \times \rho_{\text {blue }}\right)+1} \\
L S W I=\frac{\rho_{\text {nir }}-\rho_{\text {swir }}}{\rho_{\text {nir }}+\rho_{\text {swir }}} \\
N D V I=\frac{\rho_{\text {nir }}-\rho_{\text {red }}}{\rho_{\text {nir }}+\rho_{\text {red }}}
\end{gathered}
$$

where $\rho_{\text {blue }}, \rho_{\text {red }}, \rho_{\text {nir }}$, and $\rho_{\text {swir }}$ represent the surface reflectance values of blue, red, NIR, and SWIR bands, respectively $[33,39,49]$.

For time series of VIs calculated from surface reflectance, a simple approach was employed to fill those cloudy pixels $[36,50]$. The gap-filling procedure that was employed for cloudy pixels of VIs was reported in the earlier studies [22,36,39]. A three-point time series filter $X(t-1), X(t)$, and $X(t+1))$ was employed to correct a cloudy pixel using values of non-cloudy pixels in the window. If $X(t+1)$ and $X(t-1)$ pixels were cloud-free, the average of $X(t+1)$ and $X(t-1)$ was calculated and was used as $X(t)$. If only one pixel (either $X(t+1)$ or $X(t-1)$ ) was cloud-free, then we used that pixel to substitute $X(t)$. If the three-point time series filter was not available, then we expanded it to a five-point time series filter $(X(t-2), X(t-1), X(t), X(t+1)$, and $X(t+2))$ [36]. The gap filling procedure was same as the above three-point time series filter.

\subsection{The Moderate Resolution Imaging Spectroradiometer-Based Vegetation Photosynthesis Model}

\subsubsection{Model Structure}

As a RS-based vegetation photosynthesis model for simulating GPP [33], the VPM model is based on the conceptual partitioning of chlorophyll and non-photosynthetically active vegetation at the canopy. Air temperature (Ta), the EVI, LSWI, and PAR are the input data of the VPM model (Figure 2).

VPM estimates GPP over the photosynthetically active period of vegetation [33,36]:

$$
G P P=\varepsilon_{\mathrm{g}} \times F P A R_{\mathrm{chl}} \times P A R
$$

where parameter $\varepsilon_{\mathrm{g}}$ is the light use efficiency (LUE) ( $\mu \mathrm{mol} \mathrm{CO} 2 / \mu \mathrm{mol}$ photosynthetic photon flux density, PPFD), which is affected by leaf phenology, temperature, and water; parameter PAR is the photosynthetically active radiation ( $\mu \mathrm{mol}$ PPFD), and parameter $F P A R_{\mathrm{chl}}$ is the fraction of PAR absorbed by leaf chlorophyll in the canopy.

In the VPM model, $F P A R_{\text {chl }}$ is calculated as $[10,23,33,36,39,40]$ :

$$
F P A R_{\mathrm{chl}}=\alpha \times E V I
$$

where EVI is the Enhanced Vegetation Index, which is calculated from the reflectance values of the

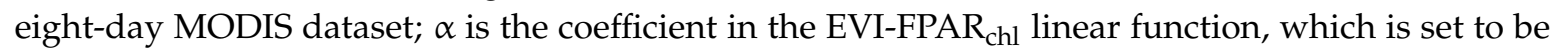
$1.0[33,36]$.

$\varepsilon_{\mathrm{g}}$ is calculated by the maximum light use efficiency (LUE) $\varepsilon_{0}\left(\mu \mathrm{mol} \mathrm{CO} \mathrm{CO}_{2} / \mu \mathrm{mol}\right.$ PPFD) and the scalars for the effects of temperature, water and leaf phenology on light use efficiency of vegetation.

$$
\varepsilon_{\mathrm{g}}=\varepsilon_{0} \times T_{\text {scalar }} \times W_{\text {scalar }} \times P_{\text {scalar }}
$$

$T_{\text {scalar }}$ is the scalar of temperature on photosynthesis, which is estimated by the Terrestrial Ecosystem Model (TEM) [51]; $W_{\text {scalar }}$ is the impact of water on vegetation photosynthesis with $L S W I_{\max }$ [40]; and, $P_{\text {scalar }}$ is the scalar for the impact of leaf phenology on photosynthesis within the canopy [39]. 


$$
\begin{gathered}
T_{\text {scalar }}=\frac{\left(T-T_{\min }\right)\left(T-T_{\max }\right)}{\left[\left(T-T_{\min }\right)\left(T-T_{\max }\right)\right]-\left(T-T_{\text {opt }}\right)^{2}} \\
W_{\text {scalar }}=\frac{1+L S W I}{1+L S W I_{\max }} \\
P_{\text {scalar }}=\frac{1+L S W I}{2}
\end{gathered}
$$

where $L S W I_{\max }$ is the maximum LSWI during 2009-2010 [15,26,27]; $T_{\max }, T_{\min }$, and $T_{\text {opt }}$ are the maximum, minimum, and optimal air temperature during photosynthesis, respectively.

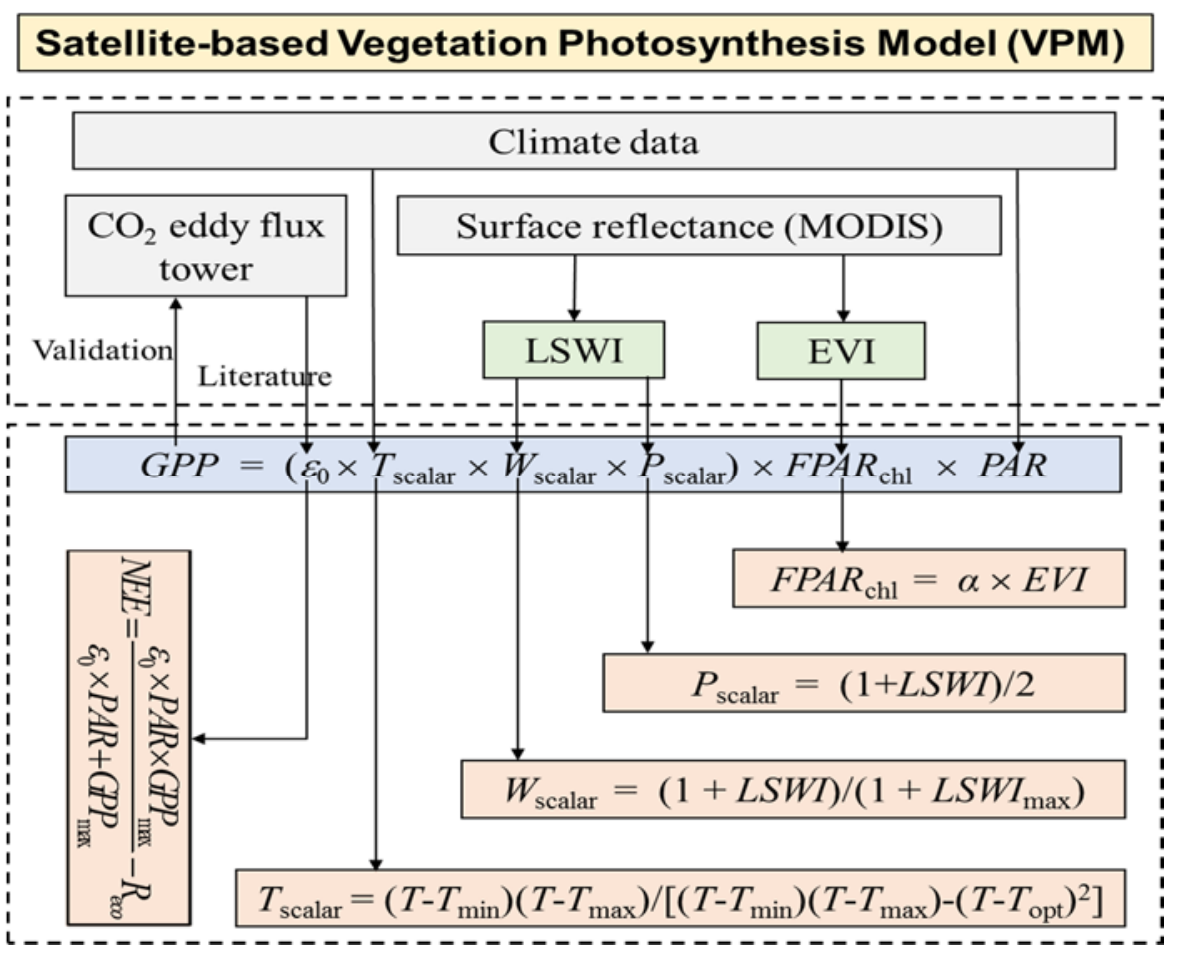

Figure 2. Structure of the vegetation photosynthesis model (VPM) model. $\mathrm{CO}_{2}$ flux and climate data (air temperature, PAR, precipitation, etc.) come from the eddy flux tower. Vegetation indices (VIs) were extracted from the Moderate Resolution Imaging Spectroradiometer (MODIS) datasets. $\varepsilon_{0}$, maximum light use efficiency; $T_{\text {scalar }}, W_{\text {scalar }}, P_{\text {scalar }}$, the scalars for the effects of temperature, water and leaf phenology on light use efficiency of vegetation, respectively; $F P A R_{\mathrm{chl}}$, the fraction of PAR absorbed by leaf chlorophyll; PAR, the photosynthetically active radiation; $L S W I_{\text {max }}$, the maximum Land Surface Water Index (LSWI); $T_{\max }, T_{\min }$, and $T_{\text {opt }}$, the maximum, minimum, and optimal air temperature, respectively.

\subsubsection{Model Parameterization}

In order to normally run the VPM model for simulating GPP of coastal wetland using input data, such as climate observation and MODIS imagery, we conducted a series of model parameterization.

Different vegetation types have a different $\varepsilon_{0}$ value. It can be obtained from analysis of NEE and photosynthetic photon flux density of the EC tower site [52,53]. In this study, we used the Michaelis-Menten function (Equation (13)) in order to estimate the $\varepsilon_{0}$ of local vegetation type by the nonlinear model between the observed NEE and incident PAR, according to the flux data at $30 \mathrm{~min}$ intervals. Here, we took $2016.67 \mathrm{mg} \mathrm{CO}_{2} \mathrm{~mol}^{-1}$ PAR as $\varepsilon_{0}$ during the study period:

$$
N E E=\frac{\varepsilon_{0} \times P A R \times G P P_{\max }}{\varepsilon_{0} \times P A R+G P P_{\max }}-R_{\mathrm{eco}}
$$


where $G P P_{\max }\left(\mathrm{mg} \mathrm{CO} \mathrm{CO}^{-2} \mathrm{~s}^{-1}\right)$ is maximum gross primary production, $R_{\mathrm{eco}}\left(\mathrm{mg} \mathrm{CO}_{2} \mathrm{~m}^{-2} \mathrm{~s}^{-1}\right)$ is ecosystem respiration, $\mathrm{NEE}\left(\mathrm{mg} \mathrm{CO} \mathrm{Cm}^{-2} \mathrm{~s}^{-1}\right)$ is the net ecosystem $\mathrm{CO}_{2}$ exchange, PAR is the photosynthetically active radiation ( $\mu \mathrm{mol}$ PPFD). Based on the diurnal GPP flux data, we chose the maximum value of GPP $\left(0.63 \mathrm{mg} \mathrm{CO}_{2} \mathrm{~m}^{-2} \mathrm{~s}^{-1}\right)$ during the study period as GPP $\max$.

Different vegetation types have different estimation values of $T_{\mathrm{scalar}}, T_{\min }, T_{\mathrm{opt}}$, and $T_{\max }$ [33]. The daily daytime mean temperature was calculated by using the daily maximum and minimum air temperature, rather than daily mean air temperature [33,54]. In our study, if the air temperature of the study site falls below $T_{\min }, T_{\text {scalar }}$ is set to zero. Because $T_{\text {scalar }}$ is the scalar of temperature on plant photosynthesis activities, we consider the local meteorological conditions and plant growth (observed GPP) comprehensively. When considering the effect of low temperature on plant growth, we finally defined $T_{\min }$ as $0{ }^{\circ} \mathrm{C}$ (cold damage to plants). Based on the observed maximum temperature during the two study years, we finally defined $T_{\max }$ as $35^{\circ} \mathrm{C}$. We also defined site-specific $T_{\mathrm{opt}}$ as $26^{\circ} \mathrm{C}$ by exploring the correlation between the observed vegetation indices, GPP and air temperature over 2009-2010.

$W_{\text {scalar }}$ can be derived from the water-sensitive vegetation index LSWI and $L S W I_{\text {max }}$. Site-specific $L S W I_{\max }$ is estimated according to the time series MODIS data [26,33,36]. As a water-sensitive vegetation index, $L S W I_{\max }$ varies across years under different water condition. Using the observed eight-day MODIS reflectance data, we calculated the site-specific LSWI values over 2009-2010 and chose the maximum value during the growing season as $L S W I_{\max }(0.27$ and 0.26 for 2009 and 2010, respectively).

\subsubsection{Model Evaluation}

In order to test VPM's applicability for coastal wetland and to check the consistency between the modeled and the observed results, four statistical criteria were used for the model evaluation: (i) the coefficient of determination $\left(R^{2}\right)$. Due to temporal autocorrelation within simulated GPP and EC-based GPP, generalized least square regression was conducted by using $g l s()$ function in $\mathrm{R}$ package $n l m e$ to adjust the residuals. Accordingly, the $\mathrm{R}^{2}$ Cox and Snell was instead used as pseudo- $\mathrm{R}^{2}$ by performing nagelkerke() function in package rcompanion; Equation (2), the root of mean square error (RMSE, Equation (14)); Equation (3), the relative mean deviation (RMD, Equation (15)); Equation (4), the relative error (RE) [55]. The RMSE provides the prediction error of model by heavily weighting high errors. The RMD can smooth out the differences between the simulated and measured results by weighting all of the errors in the same way, which when close to 0 indicate the absence of bias for the model [15,56]. We use SPSS version 20.0 (SPSS Inc., Chicago, IL, USA) and R package 3.2.1 [57] to conduct all of the statistical calculations.

$$
\begin{gathered}
R M S E=\frac{100}{\bar{O}} \sqrt{\frac{\sum_{i=1}^{n}\left(P_{i}-O_{i}\right)^{2}}{n}} \\
R M D=\frac{100}{\bar{O}} \sum_{i=1}^{n} \frac{P_{i}-O_{i}}{n}
\end{gathered}
$$

where $O_{i}$ represent the EC estimated values and $P_{i}$ represent the model-simulated values. $\bar{O}$ is the mean of the EC estimated value and $\bar{P}$ is the mean of the model-predicted value. $n$ is the number of observations.

\section{Results}

\subsection{Seasonal Dynamics of Hydrothermal Conditions, Vegetation Indices, and Gross Primary Production}

The dynamics of the main meteorological variables are given in Figure 3. There was significant seasonal variation of daily air temperature (Ta) during 2009-2010, varying between -11.0 and $33.4{ }^{\circ} \mathrm{C}$. The maximum and minimum values of Ta were found during July and January, respectively. 
But, no strong inter-annual difference among the different temperature regimes was found. The mean annual Ta were 13.9 and $13.3{ }^{\circ} \mathrm{C}$ in 2009 and 2010, respectively, both warmer than the long-term average $\left(12.1^{\circ} \mathrm{C}\right)$. The annual precipitation (rainfall and snowfall), measured at the tower in the experiment were 571.4 and $523.5 \mathrm{~mm}$ for 2009 and 2010, respectively, both higher than the long-term average $(520.0 \mathrm{~mm})$. In 2009, there were 68 days with precipitation. In 2010, there were 66 days with precipitation (Figure 3). The results also show that the rainy season started in early June, and it ended in late August.

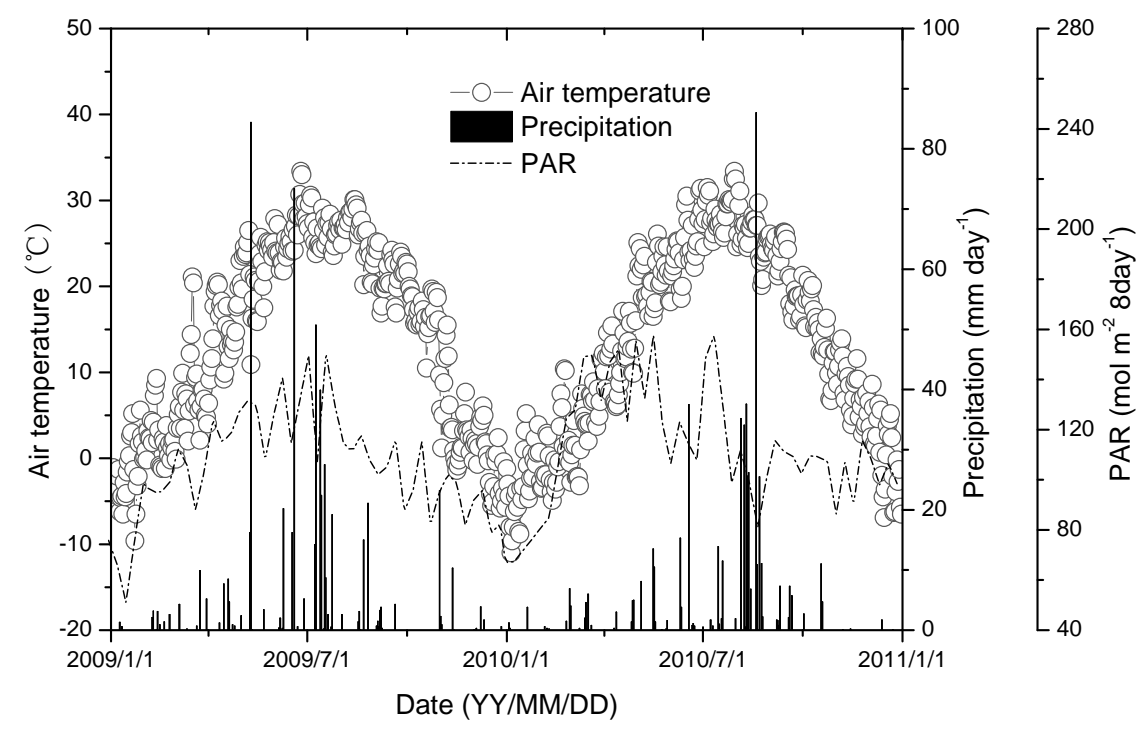

Figure 3. Seasonal variation in daily air temperature, precipitation, and aggregated eight-day PAR from eddy covariance (EC) tower during 2009-2010.

The EVI, NDVI, and LSWI curves can better demonstrate the development and the senescence of coastal wetland vegetation (Figure 4a-c). Both time series EVI and NDVI from 2009 to 2010 showed a strong seasonality for this coastal wetland ecosystem. They increased in spring and peaked in mid-August (21 August), and then declined and kept low in winter, corresponding well with the seasonal dynamics of $\mathrm{GPP}_{\mathrm{EC}}$ (Figure 4). However, seasonal variation in EVI within the growing seasons differed slightly with the NDVI in terms of phase and magnitude (Figure $4 a, b)$. The values of NDVI were obviously higher than that of EVI from late March to early November in both years. The maximum values of EVI ( 0.21 and 0.32$)$ were much lower than the peaks of NDVI ( 0.40 and 0.61$)$ in 2009 and 2010, respectively. The LSWI also exhibited seasonal variation, but it did not vary with time as significantly, as did NDVI or EVI, especially during plant growing season (Figure 4c). As shown in Figure 4c, the peak LSWI values were 0.27 (28 July) and 0.26 (12 August) for 2009 and 2010, respectively, advancing about 8-24 days as compared with the peak values of NDVI and EVI. High EVI and LSWI in August indicated that the canopy was rapidly developed photosynthetically active, while the quick drop of both EVI and LSWI in late September indicated an early plant senescence (Figure 4).

The time series $\mathrm{GPP}_{\mathrm{EC}}$ also shows an obviously seasonal and inter-annual variability (Figure 4d). With the raise of Ta and PAR, the photosynthetic capacity of coastal wetland ecosystem gradually increased. $\mathrm{GPP}_{\mathrm{EC}}$ began to increase in mid-April $\left(1 \mathrm{~g} \mathrm{C} \mathrm{m}^{-2}\right.$ day $^{-1}$ or higher), achieved the maximum values in early August (2009) or mid-July (2010), and it then decreased to below $1 \mathrm{~g} \mathrm{C} \mathrm{m}^{-2}$ day $^{-1}$ in late October (2009) or early November (2010). The peak and annual values of GPP $\mathrm{EC}_{\mathrm{E}}$ in 2009 were $9.05 \mathrm{~g} \mathrm{C} \mathrm{m}^{-2}$ and $1068.51 \mathrm{~g} \mathrm{C} \mathrm{m}^{-2}$, respectively; whereas, the respective values of GPP $\mathrm{EC}_{\text {in }} 2010$ were $9.88 \mathrm{~g} \mathrm{C} \mathrm{m}^{-2}$ and $1102.84 \mathrm{~g} \mathrm{C} \mathrm{m}^{-2}$, respectively (Figure $4 \mathrm{~d}$ ). The $\mathrm{C}$ uptake period (CUP) of wetland plant, as defined by $\mathrm{GPP}_{\mathrm{EC}}>1 \mathrm{~g} \mathrm{C} \mathrm{m}^{-2}$ day $^{-1}$, ranges from mid-April to early November, which can be partly explained by the variation of Ta and PAR (Figures 3 and $4 \mathrm{~d}$ ). Further, the growing season 
period for coastal wetland vegetation, as defined by Vis, agreed with the CUP defined by GPP $\mathrm{EC}_{\text {over }}$ the two study years (Figure $4 \mathrm{~d}$ ).

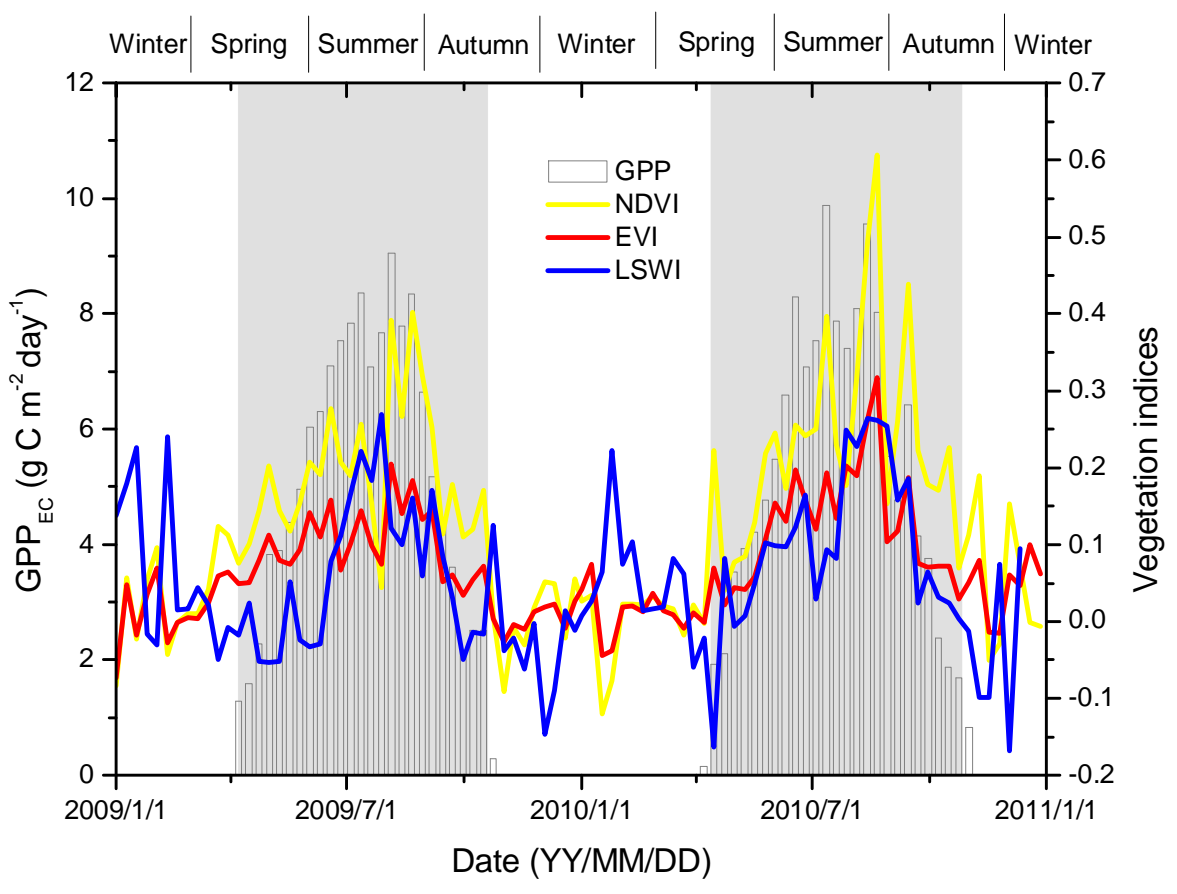

Figure 4. Seasonal dynamics of (a) Normalized Difference Vegetation Index (NDVI); (b) Enhanced Vegetation Index (EVI); (c) Land Surface Water Index (LSWI); and (d) estimated gross primary production from $\mathrm{EC}$ tower measurements $\left(\mathrm{GPP}_{\mathrm{EC}}\right)$. Three vegetation indices come from MODIS imagery during 2009-2010 in the targeted wetland.

\subsection{Correlation between GPP $E$, Vegetation Indices, and Air Temperature}

The comparisons between GPP $\mathrm{EC}_{\mathrm{C}}$ and VIs (EVI and NDVI) show that EVI has a better relationship with GPP in terms of the phase and amplitude (Figure 4). In order to further evaluate the biological significance of VIs in GPP predictions, the simple linear relationships between GPP $\mathrm{EC}_{\text {and VIs were }}$

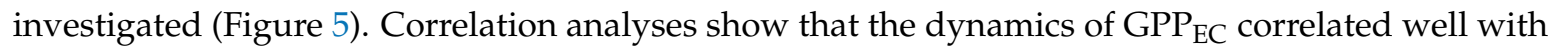
that of the VIs (EVI, NDVI, and LSWI), both in 2009 and 2010 (Figure 5). However, EVI $\left(R^{2}=0.65\right.$, $p<0.0001)$ has a better correlation with GPP $_{\mathrm{EC}}$ than NDVI does $\left(R^{2}=0.48, p<0.0001\right)$. EVI can account for $65 \%$ of the variance in $\mathrm{GPP}_{\mathrm{EC}}$, while NDVI only $48 \%$. Above results indirectly prove that the improved vegetation index EVI has a higher predictive power to simulate the GPP of the coastal wetland ecosystem. The LSWI also has a strong relationship with $\operatorname{GPP}_{\mathrm{EC}}\left(R^{2}=0.41, p<0.0001\right.$, Figure 5), showing that the land surface water content is important for the estimation of GPP during growing season.

We also analyzed the relationships between VIs (EVI, NDVI, and LSWI), GPPEC, and air temperature (Ta). The regression analysis shows that Ta was positively correlated with NDVI $\left(R^{2}=0.55\right.$, $p<0.0001)$, EVI $\left(R^{2}=0.62, p<0.0001\right)$, and $\operatorname{GPP}_{\mathrm{EC}}\left(R^{2}=0.78, p<0.0001\right)$, respectively (Figure 6a,b,d).

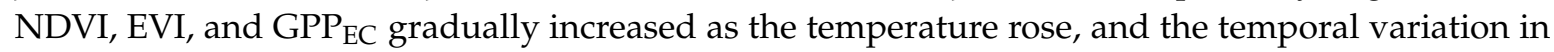
NDVI, EVI, and GPP ${ }_{E C}$ fluxes could be largely explained by air temperature. LSWI had a significant U-shaped relationship $\left(R^{2}=0.28, p<0.01\right)$ with air temperature. As temperature rose, LSWI decreased first, reached its bottom, and then increased. The demarcation point is about $10{ }^{\circ} \mathrm{C}$ (Figure $6 \mathrm{c}$ ). 

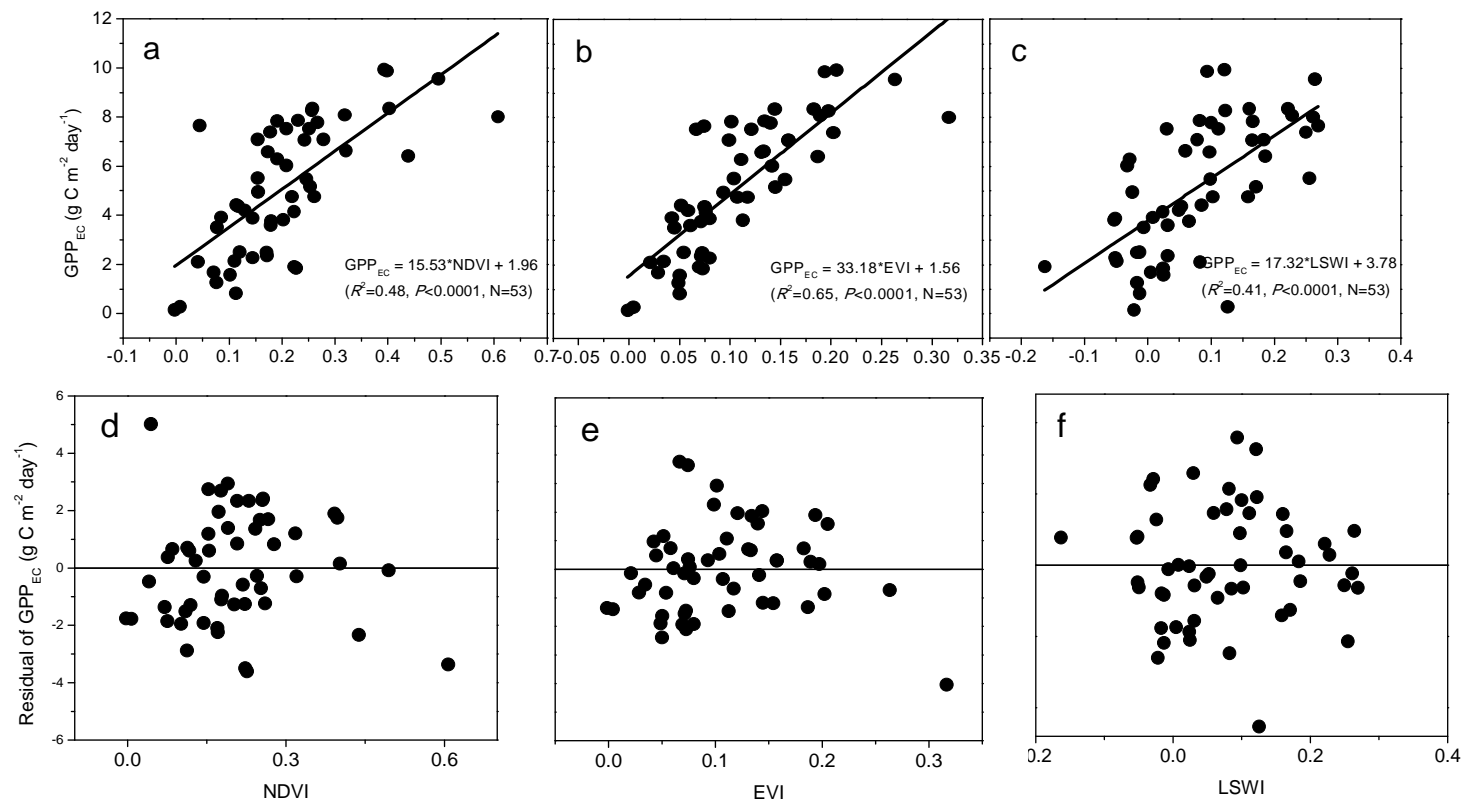

Figure 5. Linear relationships between $(\mathbf{a}, \mathbf{d})$ Normalized Difference Vegetation Index (NDVI); (b,e) Enhanced Vegetation Index (EVI); (c,f) Land Surface Water Index (LSWI) and estimated gross primary production (GPP) from EC tower data $\left(\mathrm{GPP}_{\mathrm{EC}}\right)$ during 2009-2010. Dashed lines are the linear

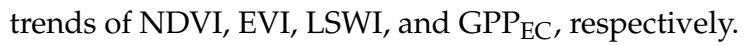

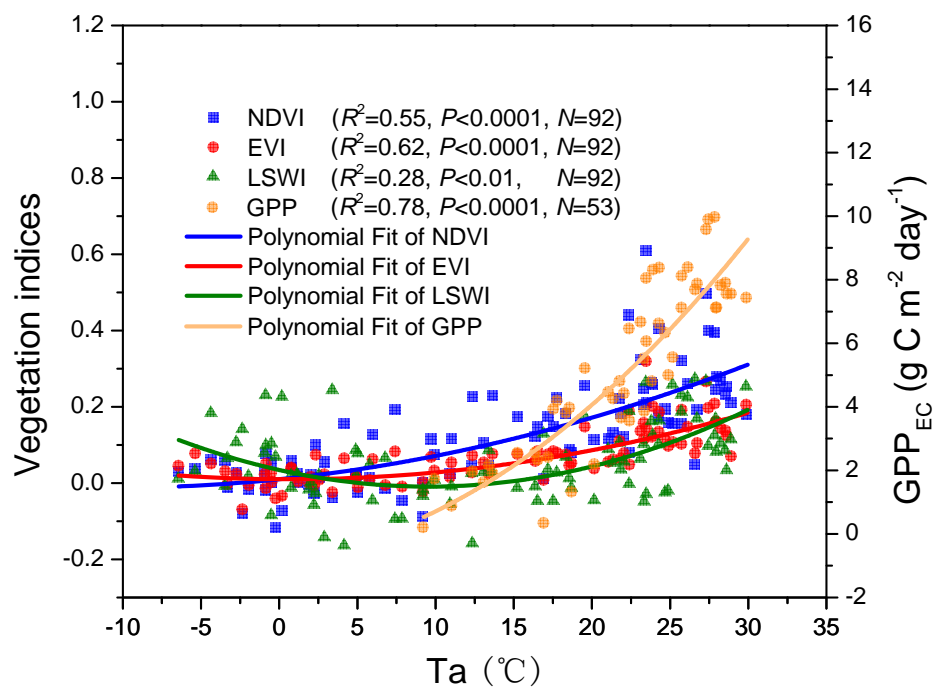

Figure 6. Linear relationships between (a) Normalized Difference Vegetation Index (NDVI); (b) Enhanced Vegetation Index (EVI); (c) Land Surface Water Index (LSWI); and (d) estimated GPP from EC tower data $\left(\mathrm{GPP}_{\mathrm{EC}}\right)$ and air temperature (Ta) during 2009-2010. NDVI $=0.00019 \cdot \mathrm{Ta}^{2}+0.004 \cdot \mathrm{Ta}+$ $0.01\left(R^{2}=0.55, p<0.0001, N=92\right) ; \mathrm{EVI}=0.0002 \cdot \mathrm{Ta}^{2}-0.0002 \cdot \mathrm{Ta}+0.01\left(R^{2}=0.62, p<0.0001, N=92\right)$; $\mathrm{LSWI}=0.00048 \cdot \mathrm{Ta}^{2}-0.0092 \cdot \mathrm{Ta}+0.034\left(R^{2}=0.28, p<0.0001, N=92\right) ; \mathrm{GPP}_{\mathrm{EC}}=0.009 \cdot \mathrm{Ta}^{2}+0.053 \cdot \mathrm{Ta}-$ $0.76\left(R^{2}=0.78, p<0.0001, N=53\right)$.

\subsection{Simulation and Evaluation of Vegetation Photosynthesis Model}

We run the VPM model based on the observation of Ta, PAR, and MODIS VIs (EVI and LSWI), and examined the seasonal variation of the modeled GPP (GPPVPM) for the tested coastal wetland during 2009-2010 (Figure 7). GPP ${ }_{\mathrm{VPM}}$ was close to zero from November to early March, then began to increase rapidly in mid-March, and achieved a peak in early-August and mid-July in 2009 and 2010, 
respectively. $\mathrm{GPP}_{\mathrm{VPM}}$ declined gradually after reaching peak it and dropped below $1 \mathrm{~g} \mathrm{C} \mathrm{m}^{-2}$ day $^{-1}$ by early-November. Comparisons between $\mathrm{GPP}_{\mathrm{VPM}}$ and $\mathrm{GPP}_{\mathrm{EC}}$ fluxes at eight-day time intervals show that the simulated eight-day GPP $\mathrm{VPM}$ fluxes were in good agreement with $\mathrm{GPP}_{\mathrm{EC}}$ fluxes regarding to the patterns and magnitudes. VPM fairly reappeared the U-shaped growth pattern, which driveled by the variation in Ta and PAR, and accurately simulated the seasonal dynamics of $\mathrm{GPP}_{\mathrm{EC}}$ fluxes for the simulated two years. However, eight-day GPP $\mathrm{VPM}$ peak values were slightly higher than $\mathrm{GPP}_{\mathrm{EC}}$ in both 2009 and 2010 (Figure 7).

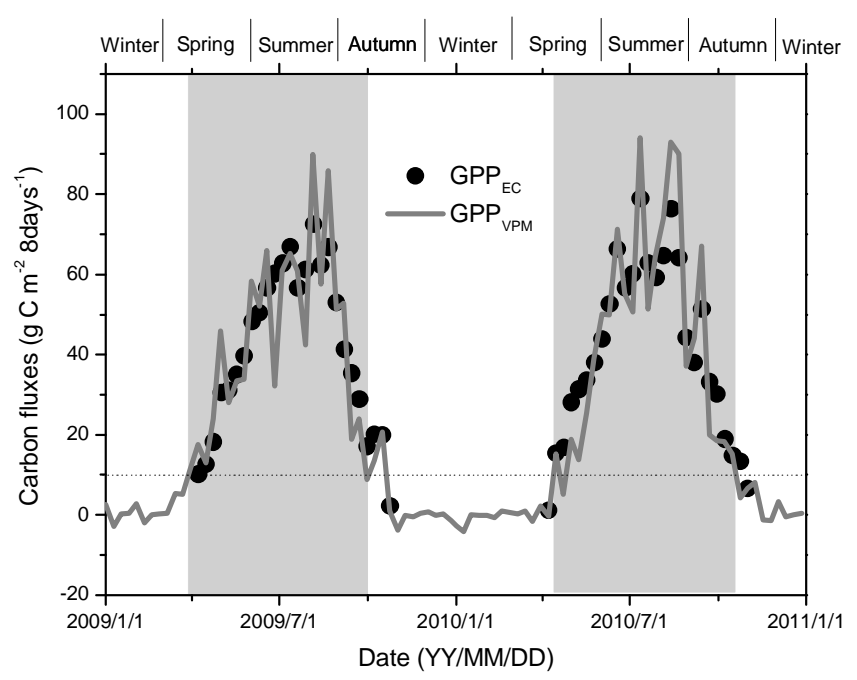

Figure 7. Comparisons of the seasonal dynamics between the estimated gross primary production from EC tower $\left(\mathrm{GPP}_{\mathrm{EC}}\right)$ and simulated gross primary production by VPM (GPP $\left.\mathrm{VPM}\right)$ during 2009-2010. Spring: March to May; Summer: June to August; Autumn: September to November; and, Winter: December to February.

To further evaluate the accuracy of model simulation, a linear regression analysis between $\mathrm{GPP}_{\mathrm{VPM}}$ and $\mathrm{GPP}_{\mathrm{EC}}$ was conducted (Figure 8). For both years, the linear regression of GPP $\mathrm{VPM}_{\text {against }} \mathrm{GPP}_{\mathrm{EC}}$ shows a good correlation $\left(R^{2} \geq 0.72, p<0.0001\right.$; Figure 8; Table 1). The RMD and RMSE values were $-1.01 \%$ and $25.29 \%$ during $2009-2010$, respectively. The simulated annual GPP ${ }_{\mathrm{VPM}}$ were 1057.64 and $1091.76 \mathrm{~g} \mathrm{C} \mathrm{m}^{-2} \mathrm{yr}^{-1}$ for 2009 and 2010, respectively, which is slightly lower than the estimated annual $\operatorname{GPP}_{\mathrm{EC}}$ (1068.51 and $1102.84 \mathrm{~g} \mathrm{C} \mathrm{m}^{-2} \mathrm{yr}^{-1}$ for 2009 and 2010, respectively), both with relative error (RE) values of $-1 \%$ (Table 1 ). Moreover, cumulative GPP fluxes simulated over the two years were in good agreement with the estimated values, with $-1 \%$ RE (Table 1 ).

Table 1. The evaluation of model simulation results in the typical coastal wetland. Four statistical criteria for the validation tests: pseudo- $R^{2}$, the coefficient of determination; RMSE, the root of mean square error; RMD, the relative mean deviation; and, $\mathrm{RE}$, the relative error.

\begin{tabular}{|c|c|c|c|c|c|c|c|c|}
\hline Items & Year & pseudo- $R^{2}$ & $\begin{array}{c}\text { RMSE } \\
(\%)\end{array}$ & $\begin{array}{c}\text { RMD } \\
(\%)\end{array}$ & $\begin{array}{c}\mathrm{GPP}_{\mathrm{EC}}{ }^{\mathrm{a}} \\
\left(\mathrm{g} \mathrm{C} \mathrm{m}^{-2}\right)\end{array}$ & $\begin{array}{l}\mathrm{GPP}_{\mathrm{VPM}}{ }^{\mathrm{a}} \\
\left(\mathrm{g} \mathrm{C} \mathrm{m}^{-2}\right)\end{array}$ & $\mathrm{RE}^{\mathrm{a}}$ & $\mathbf{N}$ \\
\hline $\mathrm{GPP}_{\mathrm{VPM}}$ & 2009 & $0.72 * * *$ & 25.09 & -1.02 & 1068.51 & 1057.64 & $-1 \%$ & 26 \\
\hline VS. & 2010 & $0.80^{* * *}$ & 25.47 & -1.00 & 1102.84 & 1091.76 & $-1 \%$ & 27 \\
\hline $\mathrm{GPP}_{\mathrm{EC}}$ & 2009-2010 & $0.73^{* * *}$ & 25.29 & -1.01 & 2171.35 & 2149.39 & $-1 \%$ & 53 \\
\hline
\end{tabular}

*** Significant at probability levels of $0.0001{ }^{\text {a }}$ Abbreviations: GPP, gross primary production; $\mathrm{GPP}_{\mathrm{EC}}$, estimated GPP from FLUX tower data; $\mathrm{GPP}_{\mathrm{VPM}}$, simulated GPP by VPM; RE (relative error) = $\left[\left(\mathrm{GPP}_{\mathrm{VPM}}-\mathrm{GPP}_{\mathrm{EC}}\right) / \mathrm{GPP}_{\mathrm{EC}}\right]$ $\times 100 \%$. 


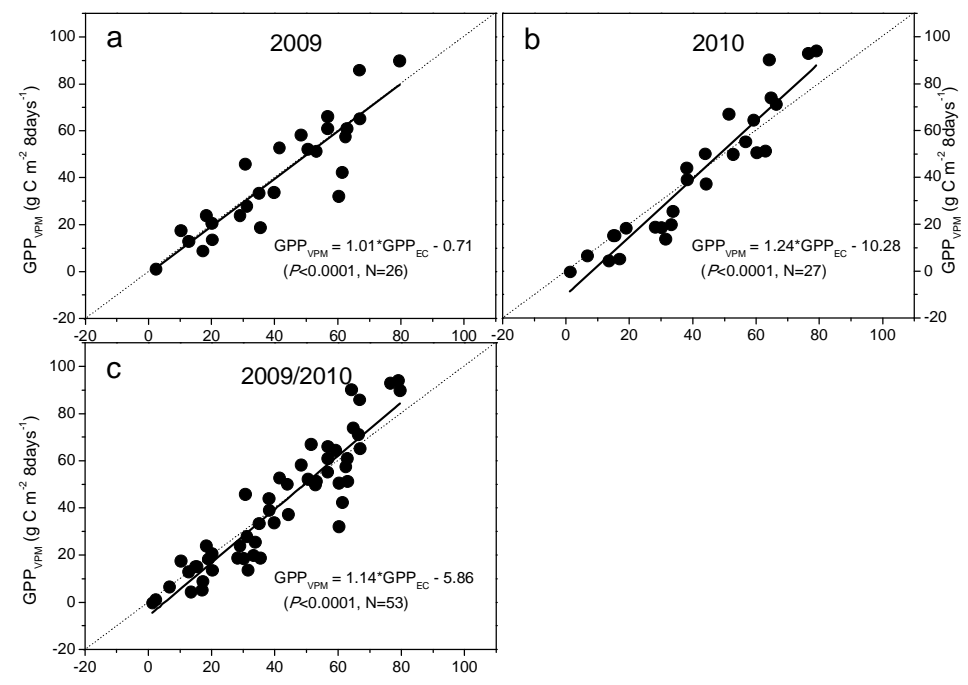

Figure 8. Linear regression analysis between the estimated gross primary production from EC tower $\left(\mathrm{GPP}_{\mathrm{EC}}\right)$ and simulated gross primary production by VPM (GPP $\left.\mathrm{VPM}\right)$ in (a) 2009; (b) 2010; and (c) 2009-2010.

\section{Discussion}

\subsection{Biophysical Performance of Vegetation Indices in Typical Coastal Wetland}

Monitoring vegetation change over time at larger scales using vegetation indices has greatly enhanced our understanding of the changing environment [58,59]. Different vegetation indices vary in their biophysical expression and they can offer distinct information for the leaf phenological cycle, which in turn, affect plant photosynthesis and regulate ecosystem carbon balance $[10,22,36]$. Some researchers have reported that time series of NDVI, EVI (greenness-related vegetation indices), and LSWI (water-related vegetation index) can be used to delineate the green-up and the senescence phase at the canopy level $[36,60]$. However, which is the best vegetation index for the model to more accurately predict the plant production in coastal wetlands remains unknown. Therefore, it is important to evaluate the biophysical and phenological expression of different vegetation indices in coastal wetland ecosystems to accurately assess vegetation phenology and predict plant production $[61,62]$.

In this study, we examined the relationship between NDVI, EVI, LSWI, and estimated GPP $\mathrm{EC}, \mathrm{Ta}$, and evaluated the biophysical expression of vegetation indices in a typical coastal wetland. Both EVI and NDVI have significant correlations with $\mathrm{GPP}_{\mathrm{EC}}$, but EVI has a stronger correlation with $\mathrm{GPP}_{\mathrm{EC}}$, and hence has more biological and phenological significance in GPP predictions than the NDVI in this coastal wetland (Figures 5 and 6). EVI can minimize the influences of soil condition and atmosphere in reflectance data by incorporating soil adjustment and atmospheric resistance factors [58]. Time series of LSWI also provide valuable information (e.g., water status) for simulating plant growth and wetland carbon exchange, even though it has a lower relationship between Ta and GPP $\mathrm{EC}_{\text {. It has a great }}$ potential in obtaining the water content information of leaf and canopy, and can more accurately identify the vegetation phenology by combining both NIR and SWIR bands $[22,63,64]$. The results in this study are consistent with earlier studies $[10,15,22,23,33,40,65,66]$, in which all indirectly prove the hypothesis of chlorophyll-FPAR $\mathrm{chl}$-EVI and leaf 1 water-LSWI, as applied in the VPM model. However, it is necessary to further develop the LSWI-based phenology algorithm in the near future [40].

\subsection{Model Comparison and Error Source Analysis}

Recently, using the LUE models to simulate GPP plays an important role in the global carbon budget research, but our understanding of relative advantages and disadvantages of different models is still limited [67]. The VPM model simulated the trends of the coastal wetland phenology well 
and precisely predicted GPP $\left(R^{2}=0.73\right)$ in this study. The MODIS-Photosynthesis (PSN) model also can simulate the global GPP and generate the Terra/MODIS GPP project (MOD17A2) $[40,68]$.

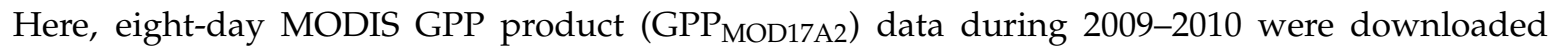
from the Oak Ridge National Laboratory's Distributed Active Archive Center (DAAC) website (http://daac.ornl.gov/MODIS) [69,70]. Then, we compared the differences between GPP $\mathrm{EC}_{\text {, GPP }}$ VPM, and GPP ${ }_{M O D 17 A 2}$ in our studied coastal wetland. A Taylor diagram was also used to display the quality of model predictions against the observations [71]. We found that both $\mathrm{GPP}_{\mathrm{EC}}$ and $\mathrm{GPP}_{\mathrm{VPM}}$ were substantially higher than GPP $\mathrm{MOD}_{17 \mathrm{~A} 2}$ in terms of the magnitudes. The underestimated range of GPP $\mathrm{MOD}_{17 \mathrm{~A} 2}$ is probably $40-80 \%$ (see Figure 9). Some previous studies also reported that the MODIS-PSN model underestimated GPP in different ecosystems [15,40,72-74]. However, Jin et al., found that $\mathrm{GPP}_{\mathrm{MOD17A2}}$ was significantly lower than $\mathrm{GPP}_{\mathrm{EC}}$ during the prophase of the growing season, but higher than $\mathrm{GPP}_{\mathrm{EC}}$ during the late growing season at broadleaf deciduous woodland [39].

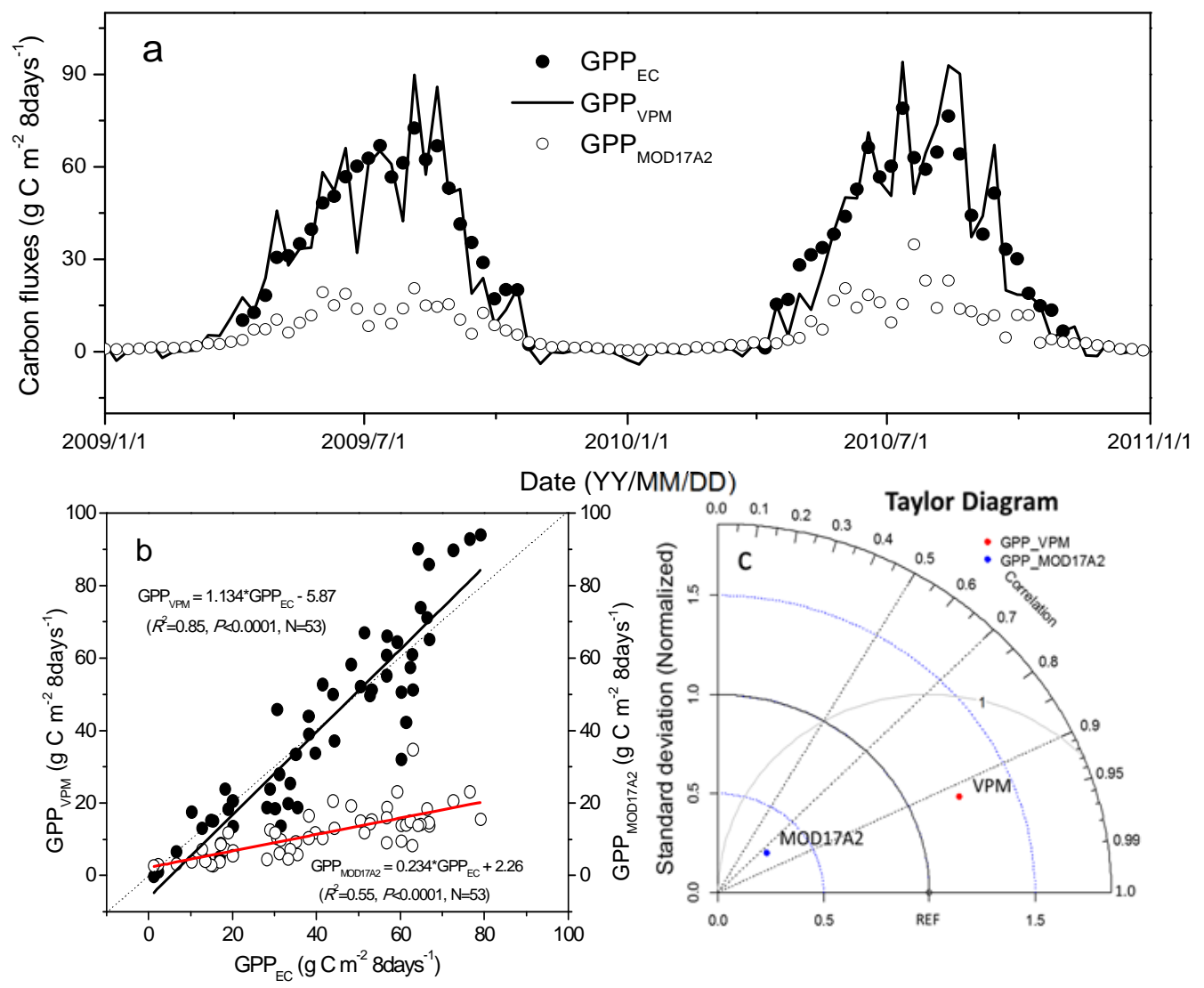

Figure 9. Comparisons between the estimated gross primary production from the flux tower $\left(\mathrm{GPP}_{\mathrm{EC}}\right)$ and simulated gross primary production by VPM (GPP $\left.\mathrm{VPM}_{\mathrm{V}}\right)$ and MODIS global GPP data product $\left(\mathrm{GPP}_{\mathrm{MOD} 17 \mathrm{~A} 2}\right)$ in the typical coastal wetland during 2009-2010. Taylor diagram provides a visual comparison between two model results, or, most commonly, between model results and observations [71].

The discrepancies between $\mathrm{GPP}_{\mathrm{MOD} 17 \mathrm{~A} 2}$ and $\mathrm{GPP} \mathrm{EC}_{\mathrm{EC}}$ may result from two underestimated sources. First, GPP ${ }_{\mathrm{MOD} 17 \mathrm{~A} 2}$ uses global meteorological reanalysis dataset, including average and minimum $\mathrm{Ta}$, incident PAR, and specific humidity. The input weather data of MODIS-PSN model may not match the local air temperature data. The second source is the parameter of $\varepsilon_{0}$ in MODIS-PSN [66,75]. $\varepsilon_{0}$ is a very important parameter in the PEM models to estimate GPP and differs significantly among vegetation types [76]. However, the $\varepsilon_{0}$ and some other biome-specific physiological parameters are not differentiated from the different performance of a specific biome [77]. The EC technique 
provides an appropriate method to accurately estimate the parameter $\varepsilon_{0}$ by using a large number of measured data $[23,30]$. In this study, we estimated the $\varepsilon_{0}$ value by fitting the nonlinear model between observed NEE and PAR in 2009 and 2010. Then, we used the site-specific climate data, the individual $\varepsilon_{0}$ estimated from $\mathrm{CO}_{2}$ flux data, and vegetation indices (EVI, LSWI) as input data and the parameters of VPM to simulate the GPP dynamics of coastal wetland. Therefore, future works should pay more attention to the local climate data and biome-specific physiological parameters in using GPPMOD17A2 for regional analysis.

\subsection{Sensitivity and Uncertainty for Vegetation Photosynthesis Model Simulations}

In general, there are always some errors in model simulations. The analysis of sources and uncertainties for the errors are very important for future improvement and the development of these models [78,79]. In this study, the VPM simulation results show that the VPM model can correctly simulate the seasonal variations of GPP. The modeled results can explain about $85 \%$ of $\mathrm{GPP}_{\mathrm{EC}}$ changes over the two study years. However, there still exist some differences between seasonal GPP $\mathrm{VPM}_{\mathrm{V}}$ and $\mathrm{GPP}_{\mathrm{EC}}$ in this study, such as higher GPP $\mathrm{VPM}_{\mathrm{V}}$ from late July to early August in 2009 and 2010, and lower GPP $\mathrm{VPM}_{\mathrm{VM}}$ in late May in 2010 (Figure 7). The discrepancies between GPP $\mathrm{EC}_{\mathrm{E}}$ and GPP $\mathrm{VPM}$ can be attributed, in part, to the estimation error of tower-based GPP $\mathrm{EC}[36,80]$. GPP $\mathrm{EC}_{\mathrm{EC}}$ is calculated as the difference between ecosystem respiration and NEE [15,36]. The estimation error of daytime ecosystem respiration, which is the difference between ecosystem respiration and observed nighttime ecosystem respiration, may lead to the error of estimation (either overestimation or underestimation) of GPP $\mathrm{EC}_{\mathrm{C}}[15,36,39,40]$.

Another error source may be attributed to the modeling of GPP ${ }_{\mathrm{VPM}}$ from VPM [33]. To further clarify the sources and uncertainty of the GPP $\mathrm{VPM}_{\mathrm{V}}$ errors, we conducted a sensitivity analysis for some parameters and variables of the model (Figure 10). The alternative sensitivity scenarios of input parameter were set by increasing Ta, $\varepsilon_{0}, \mathrm{PAR}, \mathrm{EVI}$, and LSWI by $10 \%$, respectively. When compared with the base scenario, the sensitivity of $\varepsilon_{0}$ and PAR are relatively larger than that of Ta in this coastal wetland (Figure 10a,d). The potential conversion efficiency of absorbed photosynthetically active radiation is largely determined by $\varepsilon_{0}$, which varies with vegetation types and study regions [23,39], and it may even affect the accuracy of GPP simulation [40,81]. PAR is an important variable in the GPP simulation, lower/higher PAR values may result in the under/over-estimation of GPP for the assumed relationship between GPP and PAR in VPM model $[15,82]$. Therefore, the accurate estimation of $\varepsilon_{0}$ and development of PAR observation would substantially improve the simulated accuracy of the VPM model and other models [36]. The source of uncertainty also come from the MODIS time series vegetation indices, such as the effects of cloud, cloud shadow, aerosols, and other atmospheric condition [40]. The EVI is more sensitive than LSWI to GPP simulation during 2009-2010 in this typical coastal wetland (Figure 10b,d). Future work should focus on how to avoid and mitigate the effects of angular geometry on surface albedo and to reconstruct the time series data of vegetation indices in order to improve the accuracy of vegetation indices, especially EVI.

The simulation uncertainties of VPM also come from two intermediate variables that are related to water $\left(W_{\text {scalar }}\right)$ and temperature $\left(T_{\text {scalar }}\right)$ [39]. We use the two intermediate variables to set three sensitivity scenarios, including without $T_{\text {scalar }}\left(\varepsilon_{\mathrm{g}}=W_{\text {scalar }} \times P_{\text {scalar }} \times \varepsilon_{0}\right)$, without $W_{\text {scalar }}\left(\varepsilon_{\mathrm{g}}=T_{\text {scalar }}\right.$ $\left.\times P_{\text {scalar }} \times \varepsilon_{0}\right)$, and without $T_{\text {scalar }} \& W_{\text {scalar }}\left(\varepsilon_{\mathrm{g}}=P_{\text {scalar }} \times \varepsilon_{0}\right)$. When there is no $T_{\text {scalar }}$ in the VPM, the model overestimated GPP by about 10\%, 39\%, and 25\% in 2009, 2010, and 2009-2010, respectively. In the absence of $W_{\text {scalar }}$ in VPM, the model overestimated GPP by about $18 \%, 36 \%$, and $27 \%$ in 2009, 2010, and 2009-2010, respectively. When there is no both $T_{\text {scalar }}$ and $W_{\text {scalar }}$ in VPM, the model overestimated GPP by about 31\%,57\%, and 44\% in 2009, 2010, and 2009-2010, respectively (Figure 10c,d). Above results indicated that both $T_{\text {scalar }}$ and $W_{\text {scalar }}$ have profound effects on the predicted accuracy of GPP. It will be essential to integrate both temperature and water to downscale maximum light use efficiency to better represent the impacts of temperature and water on plant photosynthesis and GPP $[36,39,40,66]$. 

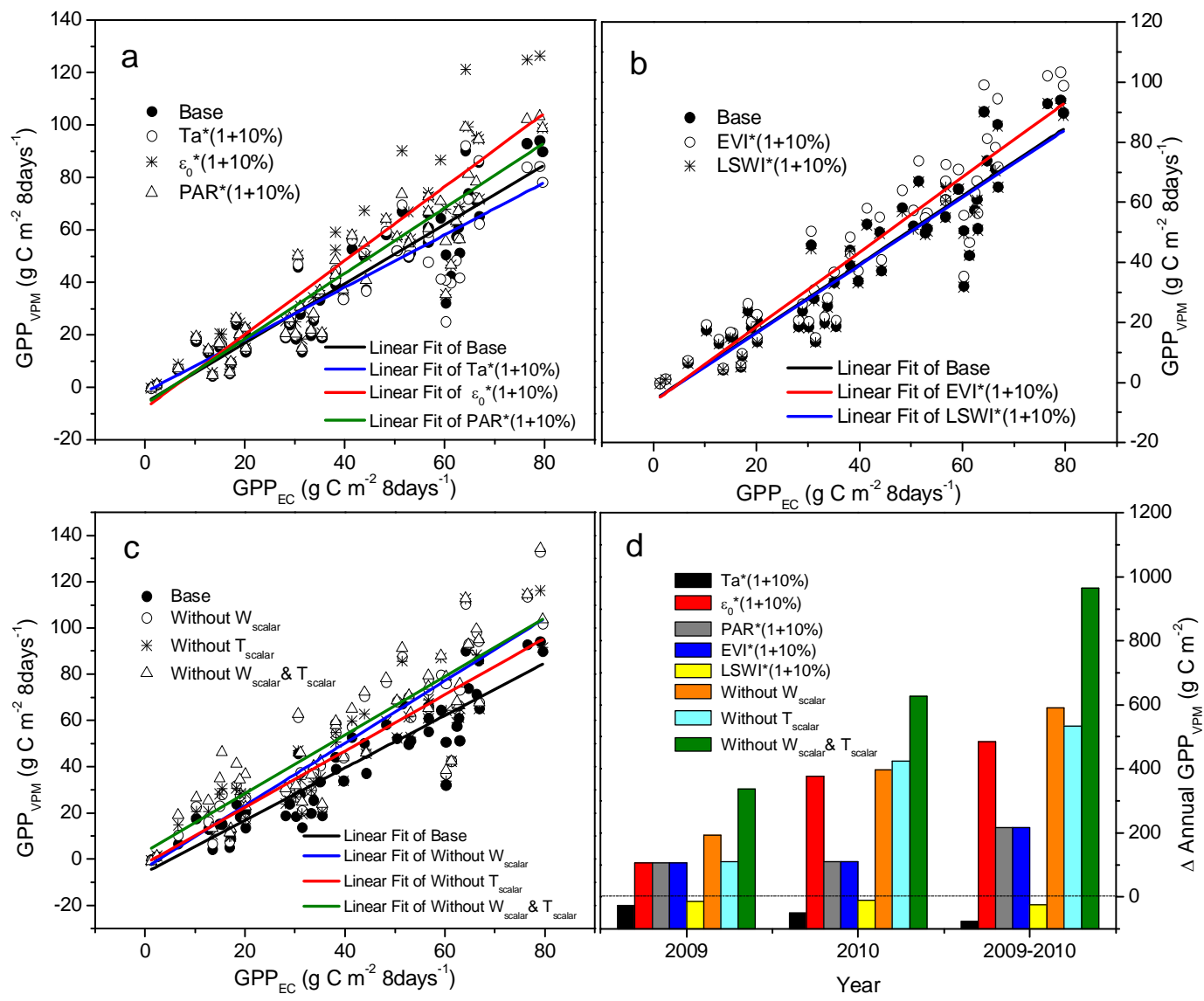

Figure 10. Parameter sensitivity analysis for VPM model in the targeted coastal wetland. GPP, gross primary production; $\mathrm{GPP}_{\mathrm{EC}}$, estimated GPP from EC tower; GPP $\mathrm{VPM}$, simulated GPP by VPM model; Ta, air temperature; $\varepsilon_{0}$, maximum light use efficiency; PAR, photosynthetically active radiation; EVI, enhanced vegetation index; LSWI, land surface water index; $W_{\text {scalar }}$ and $T_{\text {scalar }}$ are the downregulation scalars for the impacts of water and temperature on light use efficiency, respectively. Base, all of the variables do not change, $\varepsilon_{\mathrm{g}}=T_{\text {scalar }} \times W_{\text {scalar }} \times P_{\text {scalar }} \times \varepsilon_{0}$; Ta $\cdot(1+10 \%)$, increase in Ta by $10 \%$; $\varepsilon_{0} \cdot(1+10 \%)$, increase in $\varepsilon_{0}$ by $10 \%$; PAR $\cdot(1+10 \%)$, increase in PAR by $10 \%$; EVI $(1+10 \%)$, increase in EVI by $10 \%$; LSWI. $(1+10 \%)$, increase in LSWI by $10 \%$; Without $T_{\text {scalar }}, \varepsilon_{\mathrm{g}}=W_{\text {scalar }} \times P_{\text {scalar }}$ $\times \varepsilon_{0}$; Without $W_{\text {scalar }}, \varepsilon_{\mathrm{g}}=T_{\text {scalar }} \times P_{\text {scalar }} \times \varepsilon_{0} ;$ and, Without $T_{\text {scalar }} \& W_{\text {scalar }}, \varepsilon_{\mathrm{g}}=P_{\text {scalar }} \times \varepsilon_{0}$.

\section{Conclusions}

In this study, we incorporated climate and remote sensing data into a satellite-based VPM model to investigate the biophysical performance of different vegetation indices and to evaluate the applicability and accuracy of the VPM model for simulating GPP of coastal wetland in China. The results indicated that air temperature can explain most of the seasonal variation in vegetation indices and GPP $\mathrm{EC}$ fluxes. Time series of greenness-related EVI and water-related LSWI can better delineate the green-up and senescence phases of coastal wetland vegetation, which are in accordance with the CUP, as defined by $\mathrm{GPP}_{\mathrm{EC}}$. Further, both EVI and water-sensitive LSWI have higher predictive power for simulating the GPP in this coastal wetland. The EVI-based VPM model is able to simulate the U-shaped growth pattern of the coastal plant and accurately simulate the trajectories of the seasonal dynamics of GPP $\mathrm{EC}_{\mathrm{EC}}$ fluxes, explaining about $85 \%$ of $\mathrm{GPP}_{\mathrm{EC}}$ changes. Further development and improvement of VPM for nearby coastal wetlands and the spatial-temporal scale expansion are necessary for regional and continental simulations of GPP in the future. 
Author Contributions: X.K. and L.Y. contributed equally to this work. All authors contributed to designing the study, developing the overall concept of data analysis, the preparation of figures and tables, and the revision of the manuscript.

Acknowledgments: This work was supported by the National Key Research and Development Program of China (2017YFC0506203), the Natural Sciences and Engineering Research Council of Canada (NSERC) Discovery Grant and a Postdoctoral Fellowship to Xiaoming Kang from the University of Quebec at Montreal (UQAM), Canada, the National Natural Science Foundation of China (Grant No. 31770511, 41701113, 41403102,41403073). We thank the principal investigators of the MODIS data products as well as the Oak Ridge National Laboratory's (ORNL) Distributed Active Archive Center (DAAC) and the Earth Observation and Modeling Facility (EOMF), the University of Oklahoma. We thank the anonymous reviewers and editors for their valuable comments and suggestions on the earlier versions of the manuscript. We also thank Bingxue Wang for the suggestion of statistical analysis.

Conflicts of Interest: The authors declare no conflict of interest.

\section{References}

1. Choi, Y.; Wang, Y.; Hsieh, Y.P.; Robinson, L. Vegetation succession and carbon sequestration in a coastal wetland in northwest Florida: Evidence from carbon isotopes. Glob. Chang. Biol. 2001, 15, 311-319. [CrossRef]

2. Cicin-Sain, B.; Knecht, R.W.; Jang, D.; Fisk, G.W. Integrated Coastal and Ocean Management: Concepts and Practices; Island Press: Washington, DC, USA, 1998; p. 471. ISBN 978-1559636049.

3. Titus, J. Greenhouse effect and coastal wetland policy: How Americans could abandon an area the size of Massachusetts at minimum cost. Environ. Manag. 1991, 15, 39-58. [CrossRef]

4. Yanez-Arancibia, A. Terms of reference towards coastal management and sustainable development in Latin America: Introduction to Special Issue on progress and experiences. Ocean Coast. Manag. 1999, 42, 77-104.

5. Yan, Y.; Zhao, B.; Chen, J.; Guo, H.; Gu, Y.; Wu, Q.; Li, B. Closing the carbon budget of estuarine wetlands with tower-based measurements and MODIS time series. Glob. Chang. Biol. 2008, 14, 1690-1702. [CrossRef]

6. Ye, S.; Laws, E.A.; Yuknis, N.; Ding, X.; Yuan, H.; Zhao, G.; Wang, J.; Yu, X.; Pei, S.; DeLaune, R.D. Carbon sequestration and soil accretion in coastal wetland communities of the Yellow River Delta and Liaohe Delta, China. Estuar. Coast. 2015, 38, 1885-1897. [CrossRef]

7. Chen, J.; Zhang, H.; Liu, Z.; Che, M.; Chen, B. Evaluating parameter adjustment in the MODIS gross primary production algorithm based on eddy covariance tower measurements. Remote Sens. 2014, 6, 3321-3348. [CrossRef]

8. Running, S.W.; Nemani, R.R.; Heinsch, F.A.; Zhao, M.S.; Reeves, M.; Hashimoto, H. A continuous satellite-derived measure of global terrestrial primary production. Bioscience 2004, 54, 547-560. [CrossRef]

9. Tao, F.; Yokozawa, M.; Zhang, Z.; Xu, Y.; Hayashi, Y. Remote sensing of crop production in China by production efficiency models: Models comparisons, estimates and uncertainties. Ecol. Model. 2005, 183, 385-396. [CrossRef]

10. Yan, H.M.; Fu, Y.L.; Xiao, X.M.; Huang, H.Q.; He, H.L.; Ediger, L. Modeling gross primary productivity for winter wheat-maize double cropping system using MODIS time series and $\mathrm{CO}_{2}$ eddy flux tower data. Agric. Ecosyst. Environ. 2009, 129, 391-400. [CrossRef]

11. Campbell, J.E.; Berry, J.A.; Seibt, U. Large historical growth in global terrestrial gross primary production. Nature 2017, 544, 84-87. [CrossRef] [PubMed]

12. Stagg, C.L.; Schoolmaster, D.R.; Piazza, S.C. A landscape-scale assessment of above-and belowground primary production in coastal wetlands: Implications for climate change-induced community shifts. Estuar. Coast. 2017, 40, 856-879. [CrossRef]

13. Liu, Z.; Wang, L.; Wang, S. Comparison of different GPP models in China using MODIS image and ChinaFLUX data. Remote Sens. 2014, 6, 10215-10231. [CrossRef]

14. Baldocchi, D.; Falge, E.; Gu, L.H. FLUXNET: A new tool to study the temporal and spatial variability of ecosystem-scale carbon dioxide, water vapor, and energy flux densities. Bull. Am. Meteorol. Soc. 2001, 82, 2415-2434. [CrossRef]

15. Kang, X.M.; Wang, Y.F.; Chen, H.; Tian, J.Q.; Cui, X.Y.; Rui, Y.C.; Zhong, L.; Kardol, P.; Hao, Y.B.; Xiao, X.M. Modeling carbon fluxes using multi-temporal MODIS imagery and $\mathrm{CO}_{2}$ eddy flux tower data in Zoige Alpine Wetland, South-West China. Wetlands 2014, 34, 603-618. [CrossRef] 
16. Leuning, R.; Cleugh, H.A.; Zegelin, S.J.; Hughes, D. Carbon and water fluxes over a temperate Eucalyptus forest and a tropical wet/dry savanna in Australia: Measurements and comparison with MODIS remote sensing estimates. Agric. For. Meteorol. 2005, 129, 151-173. [CrossRef]

17. Wang, Y.F.; Cui, X.Y.; Hao, Y.B.; Mei, X.R.; Yu, G.Y.; Huang, X.Z.; Kang, X.M.; Zhou, X.Q. The fluxes of $\mathrm{CO}_{2}$ from grazed and fenced temperate steppe during two drought years on the Inner Mongolia Plateau, China. Sci. Total Environ. 2011, 410, 182-190. [CrossRef] [PubMed]

18. Baldocchi, D.D. Assessing the eddy covariance technique for evaluating carbon dioxide exchange rates of ecosystems: Past, present and future. Glob. Chang. Biol. 2003, 9, 479-492. [CrossRef]

19. Kang, X.M.; Hao, Y.B.; Li, C.S.; Cui, X.Y.; Wang, J.Z.; Rui, Y.C.; Niu, H.S.; Wang, Y.F. Modeling impacts of climate change on carbon dynamics in a steppe ecosystem in Inner Mongolia, China. J. Soil. Sediment. 2011, 11, 562-576. [CrossRef]

20. Song, C.; Sun, L.; Huang, Y. Carbon exchange in a freshwater marsh in the Sanjiang Plain, Northeastern China. Agric. For. Meteorol. 2011, 151, 1131-1138. [CrossRef]

21. Belshe, E.; Schuur, E.; Bolker, B.; Bracho, R. Incorporating spatial heterogeneity created by permafrost thaw into a landscape carbon estimate. J. Geophys. Res. 2012, 117, G01026. [CrossRef]

22. Kang, X.M.; Hao, Y.B.; Cui, X.Y.; Chen, H.; Huang, S.X.; Du, Y.G.; Li, W.; Kardol, P.; Xiao, X.M.; Cui, L.J. Variability and changes in climate, phenology, and gross primary production of an alpine wetland ecosystem. Remote Sens. 2016, 8, 391. [CrossRef]

23. Li, Z.Q.; Yu, G.R.; Xiao, X.M.; Li, Y.N.; Zhao, X.Q.; Ren, C.Y.; Zhang, L.M.; Fu, Y.L. Modeling gross primary production of alpine ecosystems in the Tibetan Plateau using MODIS images and climate data. Remote Sens. Environ. 2007, 107, 510-519. [CrossRef]

24. Malhi, Y. The productivity, metabolism and carbon cycle of tropical forest vegetation. J. Ecol. 2012, 100, 65-75. [CrossRef]

25. Knox, S.H.; Dronova, I.; Sturtevant, C. Using digital camera and Landsat imagery with eddy covariance data to model gross primary production in restored wetlands. Agric. For. Meteorol. 2017, 237, 233-245. [CrossRef]

26. Gamon, J.A.; Huemmrich, K.F.; Stone, R.S.; Tweedie, C.E. Spatial and temporal variation in primary productivity (NDVI) of coastal Alaskan tundra: Decreased vegetation growth following earlier snowmelt. Remote Sens. Environ. 2013, 129, 144-153. [CrossRef]

27. Zhang, A.Z.; Jia, G.S. Monitoring meteorological drought in semiarid regions using multi-sensor microwave remote sensing data. Remote Sens. Environ. 2013, 134, 12-23. [CrossRef]

28. Machwitz, M.; Gessner, U.; Conrad, C.; Falk, U.; Richters, J.; Dech, S. Modelling the gross primary productivity of West Africa with the Regional Biomass Model RBM plus, using optimized $250 \mathrm{~m}$ MODIS FPAR and fractional vegetation cover information. Int. J. Appl. Earth Obs. Geoinf. 2015, 43, 177-194. [CrossRef]

29. Potter, C.S.; Randerson, J.T.; Field, C.B.; Matson, P.A.; Vitousek, P.M.; Mooney, H.A.; Klooster, S.A. Terrestrial ecosystem production-A process model-based on global satellite and surface data. Glob. Biogeochem. Cycle 1993, 7, 811-841. [CrossRef]

30. Turner, D.P.; Ritts, W.D.; Cohen, W.B.; Gower, S.T.; Zhao, M.S.; Running, S.W.; Wofsy, S.C.; Urbanski, S.; Dunn, A.L.; Munger, J.W. Scaling gross primary production (GPP) over boreal and deciduous forest landscapes in support of MODIS GPP product validation. Remote Sens. Environ. 2003, 88, 256-270. [CrossRef]

31. Yuan, W.P.; Liu, S.; Zhou, G.S.; Zhou, G.Y.; Tieszen, L.L.; Baldocchi, D.; Bernhofer, C.; Gholz, H.; Goldstein, A.H.; Goulden, M.L.; et al. Deriving a light use efficiency model from eddy covariance flux data for predicting daily gross primary production across biomes. Agric. For. Meteorol. 2007, 143, $189-207$. [CrossRef]

32. Tucker, C.J. Red and photographic infrared linear combinations for monitoring vegetation. Remote Sens. Environ. 1979, 8, 127-150. [CrossRef]

33. Xiao, X.M.; Hollinger, D.; Aber, J.; Goltz, M.; Davidson, E.A.; Zhang, Q.Y.; Moore, B. Satellite-based modeling of gross primary production in an evergreen needleleaf forest. Remote Sens. Environ. 2004, 89, 519-534. [CrossRef]

34. Xiao, X.; Zhang, Q.; Hollinger, D.; Aber, J.; Moore, B. Modeling gross primary production of an everygreen needleleaf forest using satellite images and climate data. Ecol. Appl. 2005, 15, 954-969. [CrossRef]

35. Xiao, X.; Zhang, Q.; Saleska, S. Satellite-based modeling of gross primary production in a seasonally moist tropical evergreen forest. Remote Sens. Environ. 2005, 94, 105-122. [CrossRef] 
36. Xiao, X.M.; Zhang, Q.; Braswell, B.; Urbanski, S.; Boles, S.; Wofsy, S.; Moore, B.; Ojima, D. Modeling gross primary production of temperate deciduous broadleaf forest using satellite images and climate data. Remote Sens. Environ. 2004, 91, 256-270. [CrossRef]

37. Huete, A.R.; Liu, H.Q.; Batchily, K.; van Leeuwen, W. A comparison of vegetation indices over a global set of TM images for EOS-MODIS. Remote Sens. Environ. 1997, 59, 440-451. [CrossRef]

38. Christian, B.; Joshi, N.; Saini, M. Seasonal variations in phenology and productivity of a tropical dry deciduous forest from MODIS and Hyperion. Agric. For. Meteorol. 2015, 214, 91-105. [CrossRef]

39. Jin, C.; Xiao, X.M.; Merbold, L.; Arneth, A.; Veenendaal, E.; Kutsch, W.L. Phenology and gross primary production of two dominant savanna woodland ecosystems in Southern Africa. Remote Sens. Environ. 2013, 135, 189-201. [CrossRef]

40. Xin, F.; Xiao, X.; Zhao, B. Modeling gross primary production of paddy rice cropland through analyses of data from $\mathrm{CO}_{2}$ eddy flux tower sites and MODIS images. Remote Sens. Environ. 2017, 190, 42-55. [CrossRef]

41. Cui, B.; Yang, Q.; Yang, Z. Evaluating the ecological performance of wetland restoration in the Yellow River Delta, China. Ecol. Eng. 2009, 35, 1090-1103. [CrossRef]

42. Wang, H.; Wang, R.; Yu, Y. Soil organic carbon of degraded wetlands treated with freshwater in the Yellow River Delta, China. J. Environ. Manag. 2011, 92, 2628-2633. [CrossRef] [PubMed]

43. Wang, Y. Study on the wetland resource and biodiversity in the Yellow River Delta. J. Anhui Agric. Sci. 2007, 35, 1745-1746.

44. Zhao, T.; Song, C. Scientific Survey of the Yellow River Delta Nature Reserve; China Forestry Publishing House: Beijing, China, 1995; p. 128. ISBN 7503815345.

45. Bai, J.; Wang, J.; Yan, D. Spatial and temporal distributions of soil organic carbon and total nitrogen in two marsh wetlands with different flooding frequencies of the Yellow River Delta, China. Clean Soil Air Water 2012, 40, 1137-1144. [CrossRef]

46. Falge, E.; Baldocchi, D.; Olson, R.; Nthoni, P.; Aubinet, M.; Bernhofer, C.; Burba, G.; Ceulemans, R.; Clement, R.; Dolman, H.; et al. Gap filling strategies for defensible annual sums of net ecosystem exchange. Agric. For. Meteorol. 2001, 107, 43-69. [CrossRef]

47. Law, B.E.; Falge, E.; Gu, L. Environmental controls over carbon dioxide and water vapor exchange of terrestrial vegetation. Agric. For. Meteorol. 2002, 113, 97-120. [CrossRef]

48. Kirschbaum, M.U.F. The Temperature-Dependence of Soil Organic-Matter Decomposition, and the Effect of Global Warming on Soil Organic-C Storage. Soil Biol. Biochem. 1995, 27, 753-760. [CrossRef]

49. Huete, A.; Didan, K.; Miura, T.; Rodriguez, E.P.; Gao, X.; Ferreira, L.G. Overview of the radiometric and biophysical performance of the MODIS vegetation indices. Remote Sens. Environ. 2002, 83, 195-213. [CrossRef]

50. Xiao, X.; Braswell, B.; Zhang, Q.; Boles, S.; Frolking, S.; Moore, B. Sensitivity of vegetation indices to atmospheric aerosols: Continental- scale observations in northern Asia. Remote Sens. Environ. 2003, 84, 385-392. [CrossRef]

51. Raich, J.W.; Rastetter, E.B.; Melillo, J.M.; Kicklighter, D.W.; Steudler, P.A.; Peterson, B.J.; Grace, A.L.; Moore, B.; Vorosmarty, C.J. Potential net primary productivity in South-America-application of a global-model. Ecol. Appl. 1991, 1, 399-429. [CrossRef] [PubMed]

52. Ruimy, A.; Jarvis, P.G.; Baldocchi, D.D. $\mathrm{CO}_{2}$ fluxes over plant canopies and solar radiation: A review. Adv. Ecol. Res. 1995, 26, 1-68.

53. Goulden, M.L.; Daube, B.C.; Fan, S.M.; Sutton, D.J.; Bazzaz, A.; Munger, J.W. Physiological responses of a black spruce forest to weather. J. Geophys. Res. Atmos. 1997, 102, 28987-28996. [CrossRef]

54. Wang, Z.; Xiao, X.; Yan, X. Modeling gross primary production of maize cropland and degraded grassland in northeastern China. Agric. For. Meteorol. 2010, 150, 1160-1167. [CrossRef]

55. Smith, P.; Smith, J.; Powlson, D. A comparison of the performance of nine soil organic matter models using datasets from seven long-term experiments. Geoderma 1997, 81, 153-225. [CrossRef]

56. Huang, Y.; Yu, Y.Q.; Zhang, W. Agro-C: A biogeophysical model for simulating the carbon budget of agroecosystems. Agric. For. Meteorol. 2009, 149, 106-129. [CrossRef]

57. Coreteam, R. R: A language and environment for statistical computing. Computing 2015, 1, 12-21.

58. Karkauskaite, P.; Tagesson, T.; Fensholt, R. Evaluation of the Plant Phenology Index (PPI), NDVI and EVI for Start-of-Season Trend Analysis of the Northern Hemisphere Boreal Zone. Remote Sens. 2017, 9, 485. [CrossRef] 
59. Tian, F.; Fensholt, R.; Verbesselt, J. Evaluating temporal consistency of long-term global NDVI datasets for trend analysis. Remote Sens. Environ. 2015, 163, 326-340. [CrossRef]

60. Xiao, X.M.; Boles, S.; Liu, J.Y.; Zhuang, D.F.; Liu, M.L. Characterization of forest types in Northeastern China, using multi-temporal SPOT-4 VEGETATION sensor data. Remote Sens. Environ. 2002, 82, 335-348. [CrossRef]

61. Bradley, A.V.; Gerard, F.F.; Barbier, N. Relationships between phenology, radiation and precipitation in the Amazon region. Glob. Chang. Biol. 2011, 17, 2245-2260. [CrossRef]

62. Hmimina, G.; Dufrêne, E.; Pontailler, J.Y. Evaluation of the potential of MODIS satellite data to predict vegetation phenology in different biomes: An investigation using ground-based NDVI measurements. Remote Sens. Environ. 2013, 132, 145-158. [CrossRef]

63. Kalfas, J.L.; Xiao, X.M.; Vanegas, D.X.; Verma, S.B.; Suyker, A.E. Modeling gross primary production of irrigated and rain-fed maize using MODIS imagery and $\mathrm{CO}_{2}$ flux tower data. Agric. For. Meteorol. 2011, 151, 1514-1528. [CrossRef]

64. Reed, B.C.; Schwartz, M.D.; Xiao, X.M. Phenology of Ecosystem Processes; Springer: New York, NY, USA, 2009.

65. Liu, J.; Chen, S.; Han, X. Modeling gross primary production of two steppes in Northern China using MODIS time series and climate data. Proc. Environ. Sci. 2012, 13, 742-754. [CrossRef]

66. Wu, W.X.; Wang, S.Q.; Xiao, X.M.; Yu, G.R.; Fu, Y.L.; Hao, Y.B. Modeling gross primary production of a temperate grassland ecosystem in Inner Mongolia, China, using MODIS imagery and climate data. Sci. China Ser. D Earth Sci. 2008, 51, 1501-1512. [CrossRef]

67. Yuan, W.; Cai, W.; Xia, J. Global comparison of light use efficiency models for simulating terrestrial vegetation gross primary production based on the LaThuile database. Agric. For. Meteorol. 2014, 192, 108-120. [CrossRef]

68. Zhao, M.S.; Heinsch, F.A.; Nemani, R.R.; Running, S.W. Improvements of the MODIS terrestrial gross and net primary production global data set. Remote Sens. Environ. 2005, 95, 164-176. [CrossRef]

69. ORNL DAAC. MODIS Collection 6 Land Products Global Subsetting and Visualization Tool. ORNL DAAC: Oak Ridge, Tennessee, USA Subset Obtained for MOD17A2H Product at 37.7672 N, 119.1511 E, Time Period: 2009-01-01 to 2010-12-27, and Subset Size: $0.5 \times 0.5$ km. 2017. Available online: https:/ / doi.org/10.3334/ ORNLDAAC/1379 (accessed on 16 October 2017).

70. Running, S.; Mu, Q.; Zhao, M. MOD17A2H MODIS/Terra Gross Primary Productivity 8-Day L4 Global 500 m SIN Grid V006. NASA EOSDIS Land Processes DAAC. 2015. Available online: https://doi.org/10.5067/ MODIS/MOD17A2H.006 (accessed on 16 October 2017).

71. Taylor, K.E. Summarizing multiple aspects of model performance in a single diagram. J. Geophys. Res. Atmos. 2001, 106, 7183-7192. [CrossRef]

72. Gitelson, A.A.; Peng, Y.; Arkebauer, T.J.; Schepers, J. Relationships between gross primary production, green LAI, and canopy chlorophyll content in maize: Implications for remote sensing of primary production. Remote Sens. Environ. 2014, 144, 65-72. [CrossRef]

73. Niu, B.; He, Y.; Zhang, X. Tower-based validation and improvement of MODIS gross primary production in an alpine swamp meadow on the Tibetan Plateau. Remote Sens. 2016, 8, 592. [CrossRef]

74. Sims, D.; Rahman, A.; Cordova, V.; Elmasri, B.; Baldocchi, D.; Bolstad, P.; Flanagan, L.; Goldstein, A.; Hollinger, D.; Misson, L. A newmodel of gross primary productivity for North American ecosystems based solely on the enhanced vegetation index and land surface temperature from MODIS. Remote Sens. Environ. 2008, 112, 1633-1646. [CrossRef]

75. Goetz, S.J.; Prince, S.D.; Goward, S.N.; Thawley, M.M.; Small, J. Satellite remote sensing of primary production: An improved production efficiency modeling approach. Ecol. Model. 1999, 122, $239-255$. [CrossRef]

76. Running, S.W.; Baldocchi, D.D.; Turner, D.P. A global terrestrial monitoring network integrating tower fluxes, flask sampling, ecosystem modeling and EOS satellite data. Remote Sens. Environ. 1999, 70, 108-127. [CrossRef]

77. Wu, J.; Sun, J.; Guan, D. Site-level evaluation of MODIS-based primary production in an old-growth forest in Northeast China. J. Appl. Remote. Sens. 2011, 5, 053551. [CrossRef]

78. Walker, W.E.; Harremoës, P.; Rotmans, J. Defining uncertainty: A conceptual basis for uncertainty management in model-based decision support. Integr. Assess. 2003, 4, 5-17. [CrossRef]

79. Refsgaard, J.C.; van der Sluijs, J.P.; Højberg, A.L. Uncertainty in the environmental modelling process-a framework and guidance. Environ. Model. Softw. 2007, 22, 1543-1556. [CrossRef] 
80. Wagle, P.; Xiao, X.; Torn, M.S. Sensitivity of vegetation indices and gross primary production of tallgrass prairie to severe drought. Remote Sens. Environ. 2014, 152, 1-14. [CrossRef]

81. Sánchez, M.L.; Pardo, N.; Pérez, I.A. GPP and maximum light use efficiency estimates using different approaches over a rotating biodiesel crop. Agric. For. Meteorol. 2015, 214, 444-455. [CrossRef]

82. Zhang, J.; Hu, Y.; Xiao, X. Satellite-based estimation of evapotranspiration of an old-growth temperate mixed forest. Agric. For. Meteorol. 2009, 149, 976-984. [CrossRef]

(C) 2018 by the authors. Licensee MDPI, Basel, Switzerland. This article is an open access article distributed under the terms and conditions of the Creative Commons Attribution (CC BY) license (http://creativecommons.org/licenses/by/4.0/). 